\title{
Dopamine/Tyrosine Hydroxylase Neurons of the Hypothalamic Arcuate Nucleus Release GABA, Communicate with Dopaminergic and Other Arcuate Neurons, and Respond to Dynorphin, Met-Enkephalin, and Oxytocin
}

\author{
Xiaobing Zhang and Anthony N. van den Pol \\ Department of Neurosurgery, Yale University School of Medicine, New Haven, Connecticut 06520
}

We employ transgenic mice with selective expression of tdTomato or cre recombinase together with optogenetics to investigate whether hypothalamic arcuate (ARC) dopamine/tyrosine hydroxylase (TH) neurons interact with other ARC neurons, how they respond to hypothalamic neuropeptides, and to test whether these cells constitute a single homogeneous population. Immunostaining with dopamine and TH antisera was used to corroborate targeted transgene expression. Using whole-cell recording on a large number of neurons $(n=483)$, two types of neurons with different electrophysiological properties were identified in the dorsomedial ARC where $94 \%$ of TH neurons contained immunoreactive dopamine: bursting and nonbursting neurons. In contrast to rat, the regular oscillations of mouse bursting neurons depend on a mechanism involving both T-type calcium and A-type potassium channel activation, but are independent of gap junction coupling. Optogenetic stimulation using cre recombinase-dependent ChIEF-AAV-DJ expressed in ARC TH neurons evoked postsynaptic GABA currents in the majority of neighboring dopamine and nondopamine neurons, suggesting for the first time substantial synaptic projections from ARC TH cells to other ARC neurons. Numerous met-enkephalin (mENK) and dynorphinimmunoreactive boutons appeared to contact ARC TH neurons. mENK inhibited both types of TH neuron through G-protein coupled inwardly rectifying potassium currents mediated by $\delta$ and $\mu$ opioid receptors. Dynorphin-A inhibited both bursting and nonbursting TH neurons by activating $\kappa$ receptors. Oxytocin excited both bursting and nonbursting neurons. These results reveal a complexity of TH neurons that communicate extensively with neurons within the ARC.

Key words: arcuate nucleus; burst firing; dopamine neuron; GABA; neuropeptides; optogenetics

\section{Significance Statement}

Here, we show that the great majority of mouse hypothalamic arcuate nucleus (ARC) neurons that synthesize TH in the dorsomedial ARC also contain immunoreactive dopamine, and show either bursting or nonbursting electrical activity. Unlike rats, the mechanism underlying bursting was not dependent on gap junctions but required T-type calcium and A-type potassium channel activation. Neuropeptides dynorphin and met-enkephalin inhibited dopamine neurons, whereas oxytocin excited them. Most ventrolateral ARC TH cells did not contain dopamine and did not show bursting electrical activity. TH-containing neurons appeared to release synaptic GABA within the ARC onto dopamine neurons and unidentified neurons, suggesting that the cells not only control pituitary hormones but also may modulate nearby neurons.

\section{Introduction}

The hypothalamic arcuate nucleus (ARC) contains a complex mixture of different types of neurons based on neuropeptide syn- thesis, projections, function, and receptors. ARC cells play key roles in the regulation of pituitary secretions, energy homeostasis, feeding, and reproduction. ARC dopaminergic neurons have A.N.v.d.P. wrote the paper.

This work was supported by National Institutes of Health Grants NS048476 and DK084052. We thank Yang Yang for technical assistance; and John N. Davis, Daniel Spergel, and Andrew Zayachkivsky for suggestions.
Copyright $\odot 2015$ the authors $\quad 0270-6474 / 15 / 3514966-17 \$ 15.00 / 0$ 
been considered as a single group of neurons that project to the median eminence where axon terminals release dopamine into the hypophyseal portal circulation to inhibit pituitary prolactin secretion (Kawano and Daikoku, 1987). The focus on the role of these cells in the regulation of pituitary secretions is emphasized by the name often used for these cells, tuberoinfundibular dopamine neurons. Prolactin promotes milk synthesis, enhances maternal behavior, inhibits pregnancy, and increases weight gain (Freeman et al., 2000; Grattan et al., 2001). Prolactin secretion is tonically inhibited by dopamine released from ARC neurons (Ben-Jonathan, 1985; Ben-Jonathan and Hnasko, 2001). Dopamine neurons of the dorsomedial ARC (dmARC), the focus of our work, express the enzyme $\mathrm{TH}$, the primary dopamine vesicular transporter VMAT2, the inward dopamine transporter DAT which transports dopamine into neurons from extracellular sites, including around axon terminals, and dopamine (Zoli et al., 1993; Björklund and Dunnett, 2007) [Allen Brain Atlas (www. brain-map.org/)]. In addition to a role in prolactin regulation, ARC dopamine neurons may be involved in other systems, suggested by their response to stress (Moore et al., 1987), sensitivity to monosodium glutamate that is toxic to these cells (Lin and Pan, 1999), and response to glucoprivation (Briski, 1998). The melanocortin agonist MTII was recently shown to evoke a rapid reduction in metabolism and an active hypothermic state by a mechanism based on activation of ARC dopamine neurons (Lute et al., 2014), suggesting the potential for modulation of ARC dopamine neurons by nearby ARC pro-opiomelanocortin neurons. On the basis of immunocytochemical studies, ARC TH neurons also synthesize GABA (Everitt et al., 1984), the opioid neuropeptide enkephalin (Merchenthaler, 1994), and neurotensin (Ibata et al., 1983).

Both dynorphin (Dyn) and met-enkephalin (mENK) increase prolactin secretion during lactation (Kiem et al., 1988; Butelman et al., 1999). Suckling-induced prolactin increases are blocked by opioid receptor antagonists (Cusan et al., 1977; Dupont et al., 1977; Van Vugt et al., 1981; Matsushita et al., 1982; Callahan et al., 2000). Other hypothalamic neuropeptides such as oxytocin also modulate prolactin secretion (Kennett and McKee, 2012). Whether these effects may be due to modulation of ARC TH neurons is addressed here.

We use novel TH-tdTomato transgenic mice to identify and characterize the electrophysiological characteristics of ARC dopamine neurons; selectivity of expression is confirmed with $\mathrm{TH}$ and dopamine antisera. To obtain selective expression of the channelrhodopsin variant ChIEF specifically in ARC TH neurons, an adeno-associated virus vector encoding Cre-dependent ChIEF was injected into the ARC of TH-cre mice. This approach allowed us to study the neuropeptide responses of ARC TH cells and to investigate their substantial local projections to other cells of the ARC.

\section{Materials and Methods}

Animals. TH-tdTomato male and female transgenic mice were generated and provided by Gensat/ Rockefeller University and are characterized here. We also used TH-Cre mice (Savitt et al., 2005), a kind gift from Drs. R. Greene, J. Zigman, T. Dawson, and J. Savitt. All animals and procedures in this study were approved by the Yale University Committee on Animal Care and Use.

Virus injection. TH-Cre mice ( $6-8$ weeks old, male and female) were anesthetized with xylazine $(20 \mathrm{mg} / \mathrm{kg})$ and ketamine $(100 \mathrm{mg} / \mathrm{kg})$ and placed into a stereotaxic apparatus. After exposing the skull via a small incision, a small hole was drilled for injection. A pulled-glass pipette with a $20-40 \mu \mathrm{m}$ tip diameter was beveled and inserted into the ARC (coordinates, bregma: anteroposterior, $-1.30 \mathrm{~mm}$; dorsoventral, $-5.90 \mathrm{~mm}$; lateral, $-0.20 \mathrm{~mm}$ ) and Cre-dependent adeno- associated virus (AAV-DJ)-ChIEF-tdTomato (Lin et al., 2009) (from Stanford University Viral Vector Core) (100 nl, titer: $2.4 \times 10^{9}$ infectious units $/ \mathrm{ml}$ ) was bilaterally injected using an air pressure system. AAV-DJ is an effective recombinant chimeric AAV consisting of a combination of sequences from multiple different AAV serotypes (Grimm et al., 2008; Melo et al., 2014). A microinjector was used to control the injection speed at $30 \mathrm{nl} / \mathrm{min}$, and the pipette was slowly withdrawn $5 \mathrm{~min}$ after injection. Optogenetic experiments and related immunostaining were performed at least 2 weeks after virus injection.

Electrophysiology. Slices containing the ARC were obtained from transgenic mice that selectively express tdTomato in TH neurons. Male and female mice (14- to 84-d-old) were used and housed in a climate-controlled environment at $22^{\circ} \mathrm{C}$ with a $12 / 12 \mathrm{~h}$ light/dark cycle and ad libitum access to food and water. As we found no substantive differences between the young and older mice, or between male and female, data were pooled in some experiments. On the day of the experiment, mice were anesthetized with isoflurane and decapitated. Brains were quickly removed and immersed in ice-cold highsucrose solution containing (in $\mathrm{mm}$ ) the following: 220 sucrose, 2.5 $\mathrm{KCl}, 6 \mathrm{MgCl}_{2}, 1 \mathrm{CaCl}_{2}, 1.23 \mathrm{NaH}_{2} \mathrm{PO}_{4}, 26 \mathrm{NaHCO}_{3}$, and 10 glucose (gassed with $95 \% \mathrm{O}_{2} / 5 \% \mathrm{CO}_{2} ; 300-305 \mathrm{mOsm}$ ). Coronal brain slices (300 $\mu \mathrm{m}$ thick) containing the hypothalamus were prepared using a vibratome. Brain slices were transferred to an incubation chamber filled with ACSF solution containing the following (in mM): $124 \mathrm{NaCl}$, $2.5 \mathrm{KCl}, 2 \mathrm{MgCl}_{2}, 2 \mathrm{CaCl}_{2}, 1.23 \mathrm{NaH}_{2} \mathrm{PO}_{4}, 26 \mathrm{NaHCO}_{3}$, and 10 glucose (gassed with $95 \% \mathrm{O}_{2} / 5 \% \mathrm{CO}_{2} ; 300-305 \mathrm{mOsm}$ ) and incubated at room temperature $\left(22^{\circ} \mathrm{C}\right)$. After a $1-2 \mathrm{~h}$ recovery period, slices were transferred to a recording chamber mounted on a BX51WI upright microscope (Olympus) and perfused with a continuous flow of gassed ACSF. Experiments were performed at $33 \pm 1^{\circ} \mathrm{C}$ using a dual-channel heat controller (Warner Instruments).

Whole-cell patch-clamp recordings were performed on tdTomatoexpressing neurons that were visualized using a tdTomato filter set and an infrared-differential interference contrast optical system combined with a monochrome CCD camera and monitor. Pipettes used for wholecell recording were pulled from thin-walled borosilicate glass capillary tubes (length $75 \mathrm{~mm}$, outer diameter $1.5 \mathrm{~mm}$, inner diameter $1.1 \mathrm{~mm}$, World Precision Instruments) using a P-97 Flaming/Brown micropipette puller (Sutter Instruments) and had resistances ranging from 4 to 6 $\mathrm{M} \Omega$ when filled with pipette solution containing the following (in $\mathrm{mm}$ ): $145 \mathrm{~K}$-gluconate (or $\mathrm{KCl}$ for IPSCs in some experiments), 1 $\mathrm{MgCl}_{2}, 10$ HEPES, 1.1 EGTA, $2 \mathrm{Mg}$-ATP, $0.5 \mathrm{Na}_{2}$-GTP, and $5 \mathrm{Na}_{2}$ phosphocreatine, pH 7.3 with $\mathrm{KOH}(290-295$ mOsm). Pipettes were connected via an $\mathrm{Ag}-\mathrm{AgCl}$ electrode to the headstage of an EPC-10 patch-clamp amplifier (HEKA Instruments). The reference electrode was a silver-silver chloride pellet immersed in the bath solution. Pipette and cell capacitance were compensated using PatchMaster 2.20 software (HEKA Elektronik). Membrane potentials in the results are corrected for the $9 \mathrm{mV}$ liquid junction potential. Neurons in which the series resistance was $>20 \mathrm{M} \Omega$ and changed $>15 \%$ were excluded from the statistics. PatchMaster 2.20 was used to acquire and analyze the data. Traces were processed using Igor Pro 6.36 (Wavemetrics). Spontaneous postsynaptic currents were analyzed with MiniAnalysis 6.03 (Synaptosoft). Additional description of electrophysiological methods can be found elsewhere (Acuna-Goycolea et al.,2005; van den Pol et al., 2009; Zhang and van den Pol, 2013).

In some experiments, optogenetic activation of channelrhodopsin channels was evoked by stimulation with an LED array (BXRAC2002, Bridgelux). Duration (10 ms) and frequency (single stimulation, 1 or $10 \mathrm{~Hz}$ ) of stimulation were set with a Grass S44 stimulator (Natus Neurology). A photostimulus intensity of $5-10 \mathrm{~mW} / \mathrm{mm}^{2}$ was used to evoke maximal responses. Blue light $\left(470 \mathrm{~nm}, 5-10 \mathrm{~mW} / \mathrm{mm}^{2}\right)$ generated by the laser with an optical stimulus tip (diameter $50 \mu \mathrm{m}$, NA 0.22 , Doric Lenses) was also used to selectively stimulate the arcuate nucleus in hypothalamic slices. The optogenetic stimulation from both LED and laser produced similar synaptic GABA release.

Immunocytochemistry. To corroborate the neuronal phenotype of neurons that expressed tdTomato or ChIEF-tdTomato in transgenic THtdTomato mice or TH-Cre mice injected with AAV Cre-dependent 
ChIEF-tdTomato, and to determine whether Dyn and mENK may be released by axon terminals near TH neurons, we combined detection of green immunofluorescence with detection of tdTomato (red fluorescence). Mice were anesthetized with sodium pentobarbital, and then perfused transcardially with saline followed by $4 \%$ PFA. The $16-\mu$ m-thick coronal sections were cut on a cryostat, immersed in PBS for $1 \mathrm{~h}$, treated with 2\% normal horse serum in PBS for $1 \mathrm{~h}$, and then incubated overnight at $4^{\circ} \mathrm{C}$ in polyclonal rabbit Dyn-A antibody (1:2500; from Phoenix Pharmaceuticals), mENK antibody (1:1000; Millipore), or TH antibody (1:3000; Millipore) that were described in detail by the antibody manufacturer and elsewhere (Williams and Dockray, 1983; Sztainberg et al., 2011; Tritsch et al., 2012; Zhang and van den Pol, 2013). After washing in PBS, sections were placed in secondary Alexa488- or Alexa594-conjugated donkey anti-rabbit IgG at a dilution of 1:250 for $2 \mathrm{~h}$, washed, and mounted on glass slides. Sections were studied on an Olympus IX70 inverted fluorescence microscope. Micrographs were recorded with a SPOT digital camera (Diagnostic Instruments), and contrast and brightness were corrected using Photoshop CS4.

For dopamine immunostaining, we fixed the mouse brain with $1 \%-3 \%$ glutaraldehyde. A rabbit anti-dopamine antibody (from Dr. H. Steinbusch at Maastricht University) was used to corroborate that dopamine immunoreactivity is found in the dorsomedial ARC TH neurons. The dopamine antibody has been thoroughly characterized (Steinbusch et al., 1986; Steinbusch and Tilders, 1987; Zoli et al., 1993).

Statistical analysis. Data are expressed as mean \pm SEM. Group statistical significance was assessed using Student's $t$ test for comparison of two groups, and one-way ANOVA followed by a Bonferroni post hoc test for three or more groups. $p<0.05$ was considered statistically significant.

Drugs and drug application. Dyn-A (1-13, human, rat, porcine), mENK, and oxytocin were purchased from Phoenix Pharmaceuticals. Guanosine $5^{\prime}$ - $[\beta$-thio $]$ diphosphate trilithium salt (GDP- $\beta$-s), Nor-Binaltorphimine dihydrochloride (Nor-BNI), D-Phe-Cys-TyrD-Trp-Arg-Thr-Pen-Thr-NH2 (CTAP), iberiotoxin, SDM25N, TTX, bicuculline (Bic), CNQX, AP5, and ZD7288 were from Tocris Bioscience. 4-AP, mENK, carbenoxolone (CBX), 18- $\beta$-glycyrrhetinic acid (18 $\beta$-GA), and other drugs used were from SigmaAldrich. Drugs were prepared and stored as

stock solutions according to the manufacturer's instructions and diluted in ACSF to obtain the experimental concentrations before each experiment. All drug solutions were administered by a large diameter $(300 \mu \mathrm{m})$ flow pipe with the tip directed toward the recorded cell. During periods of no drug application, normal ACSF was continuously supplied to the recorded cell through the flow pipe.

\section{Results}

Identification of dopamine neurons in TH-tdTomato transgenic mice

Because these mice have apparently not been previously characterized, and to confirm that the neurons expressing tdTomato also

VTA

$\mathrm{OB}$

\section{tdTomato Anti-TH}
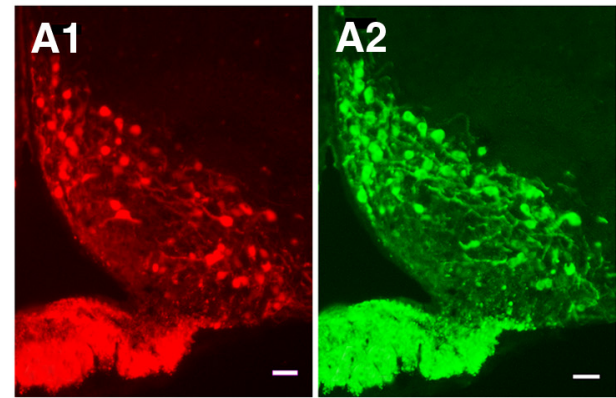

\section{Overlay}
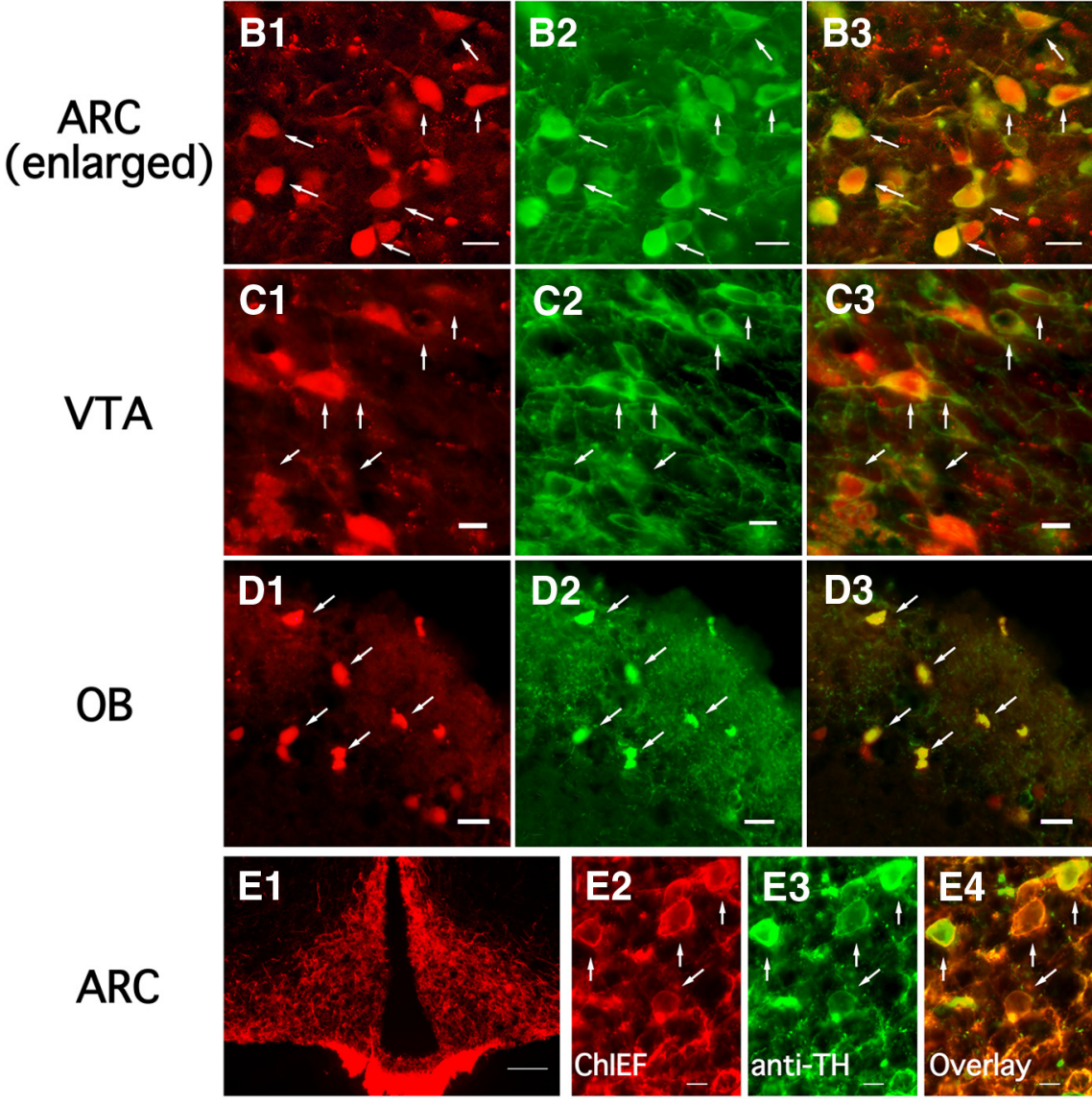

Figure 1. TH expression in TH-tdTomato transgenic mice. $\boldsymbol{A 1}, \boldsymbol{A 2}$, TH-tdTomato fluorescence ( $\boldsymbol{A} \mathbf{1})$ and TH immunostaining (A2) showing fluorescence was restricted to the ARC. Scale bar, $20 \mu \mathrm{m}$. B1-B3, Enlarged images showing TH-tdTomato fluorescence (B1), TH immunostaining (B2), and the overlay (B3) in the ARC. Scale bar, $10 \mu \mathrm{m}$. C1-C3, TH-tdTomato fluorescence (C1), TH immunostaining (C2), and the overlay (C3) in the ventral tegmental area (VTA). Scale bar, $10 \mu \mathrm{m}$. D1-D3, TH-tdTomato fluorescence (D1), TH immunostaining (D2), and the overlay (D3) in the olfactory bulb. Scale bar, $10 \mu \mathrm{m}$. E, Restricted ChIEF-tdTomato expression was found after AAV Cre-dependent ChIEF-tdTomato was injected into both sides of the ARC of TH-Cre mice (E1). Scale bar, $200 \mu \mathrm{m}$. High-magnification image showing cell bodies of ChlEF-tdTomato-expressing neurons (E2), TH-immunostained neurons (E3), and the overlay (E4). Cells expressing ChlEF-tdTomato were immunoreactive for TH. Scale bar, $20 \mu \mathrm{m}$.

synthesized TH, we first used $\mathrm{TH}$ antiserum to stain neurons of the TH-tdTomato mice. In the medial hypothalamus, the tdTomato and green anti-TH immunofluorescence was restricted to the ARC and was absent in cells of the neighboring ventromedial nucleus (Fig. $1 A 1, A 2)$. We found colocalization of red tdTomato and green anti-TH fluorescence in neurons of the ARC (Fig. 1B1-B3), and in other areas previously shown to contain $\mathrm{TH}$-positive neurons, including the ventral tegmental area (Fig. 1C1-C3) and olfactory bulb (Fig. 1D1-D3). TH tdTomato-expressing cells were found in all areas in which TH-positive neurons were identified by previous studies (Hökfelt et al., 1976; Javoy-Agid et al., 1981; Piotte et al., 1985; 

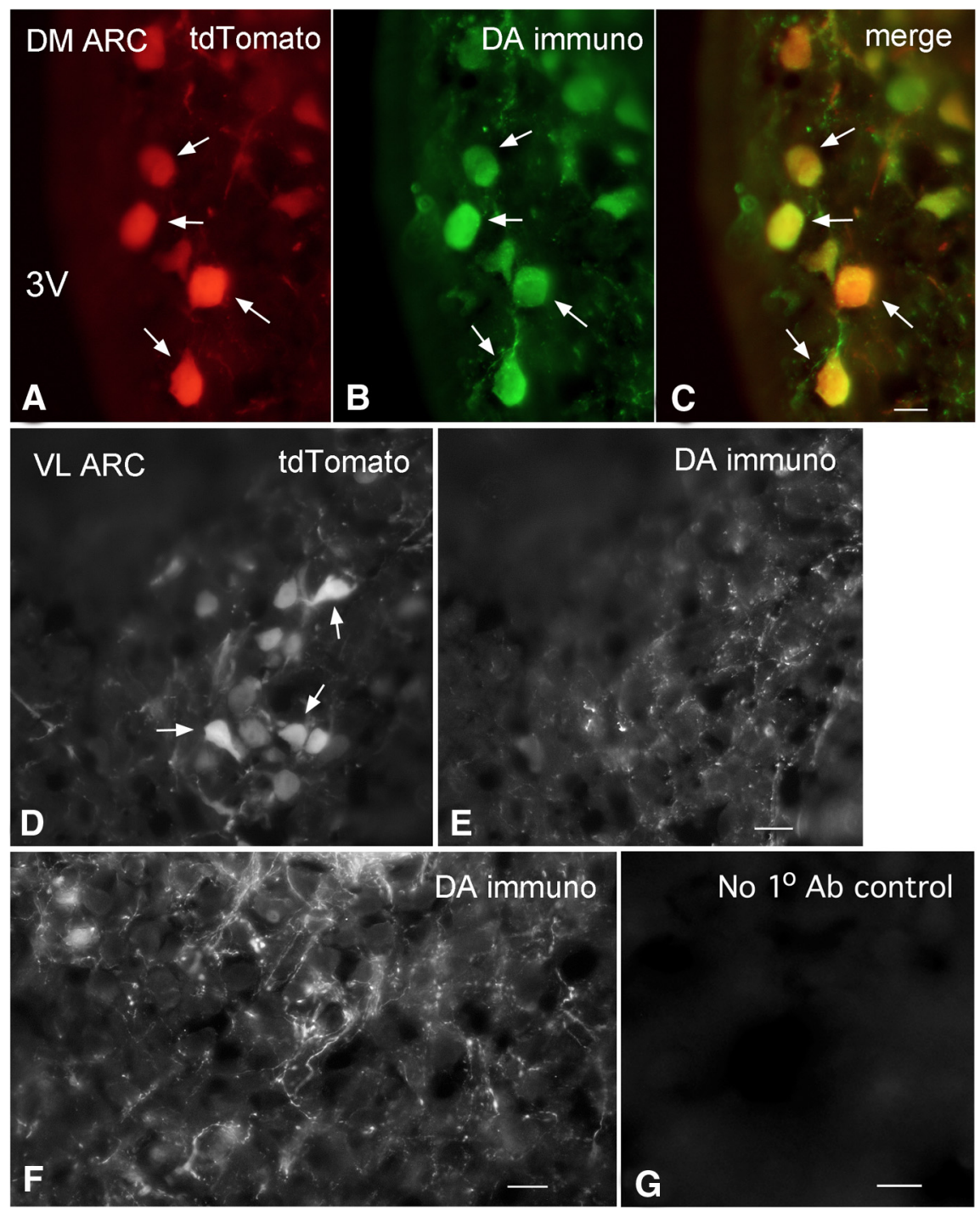

Figure 2. Dopamine immunoreactivity in TH-tdTomato mice. $\boldsymbol{A}-\boldsymbol{C}$, Dopamine immunoreactivity in tdTomato neurons in $\operatorname{dmARC}$. $\boldsymbol{A}$, Red tdTomato-positive neurons from transgenic reporter mouse. $\boldsymbol{B}$, Green neurons immunostained for dopamine. $\boldsymbol{C}$ Merge of $\boldsymbol{A}$ and $\boldsymbol{B}$ shows that most tdTomato neurons also show dopamine immunoreactivity. Scale bar, $9 \mu \mathrm{m}$. $\boldsymbol{D}, \mathrm{In}$ vIARC, tdTomato-positive neurons are found (arrows). $\boldsymbol{E}$, Dopamine immunostaining showed primarily immunoreactive axons with few neurons showing both dopamine-immunoreactive and tdTomato expression. Scale bar, $12 \mu \mathrm{m}$. $\boldsymbol{F}$, Dopamine-immunoreactive axons are seen surrounding unidentified ARC neurons. Scale bar, $9 \mu \mathrm{m}$. G, Here, the primary dopamine antibody was omitted, and only the secondary antibody was applied as a control. No immunostaining was found. Scale bar, $10 \mu \mathrm{m}$.

indicator of dopamine neurons (Björklund and Dunnett, 2007). However, TH can also be expressed in neurons that may not actively contain dopamine. To address the question of whether the tdTomato-positive neurons in the ARC were immunoreactive for dopamine, we used a characterized dopamine antibody (Steinbusch et al., 1986; Steinbusch and Tilders, 1987; Zoli et al., 1993). In the dmARC, the great majority of tdTomato-expressing neurons also showed dopamine immunoreactivity (Fig. 2A-C). Of 209 red neurons in the dmARC, 197 (94\% based on 3 adult mice) also showed green dopamine immunofluorescence, indicating that, in the dmARC, the tdTomato reporter driven by a $\mathrm{TH}$ gene promoter was a good marker for dopamine neurons. In contrast, in the vlARC the majority of tdTomato-positive cells did not show dopamine immunoreactivity (Fig. 2D,E). Of 264 tdTomatopositive cells in the ventrolateral part of the nucleus, only $26 \quad(10 \%)$ were dopamine-immunoreactive. Dopamineimmunoreactive axons were found surrounding neurons in both vlARC and dmARC (Fig. 2F). ARC dopamine immunoreactivity was found in both the vlARC and dmARC paralleling descriptions of dopamine transporter expression in the ARC (Turiault et al., 2007). Dopamine immunostaining was also found in corresponding patterns outside the arcuate nucleus as previously reported in other species (Steinbusch et al., 1986; Plantjé et al., 1987; Steinbusch and Tilders, 1987; Zoli et al., 1993). These data are consistent with a previous report in rats (Zoli et al., 1993) that found that almost all THpositive cells in the dmARC also contained dopamine, but that only a minority of TH cells in the vlARC showed dopamine immunoreactivity.

Bayer and Pickel, 1990). In ARC neurons, both tdTomato red fluorescence and green anti-TH immunofluorescence were bright and clear. Neurons in both the ventrolateral (vl) and dorsomedial (dm) ARC were positive for reporter gene expression of $\mathrm{TH}$ immunoreactivity. Almost all of the tdTomato-positive neurons identified in the ARC of 15 sections from two female and one male 2-month-old mice showed immunoreactivity for TH: $98.6 \pm 0.9 \%$ of a total of 709 tdTomato-positive neurons were immunostained with $\mathrm{TH}$ antiserum, and $97.5 \pm 0.6 \%$ of $710 \mathrm{TH}$-immunostained neurons were tdTomato-positive. Adrenergic and noradrenergic neurons also use $\mathrm{TH}$, but these cells are not found in the ARC (Foster et al., 1985; Ruggiero et al., 1985; Leshin et al., 1995; Leshin et al., 1996).

In the absence from neurons of the hypothalamus of dopamine $\beta$ hydroxylase and phenylethanolamine $N$-methyl transferase, the enzymes for norepinephrine and epinephrine synthesis, TH-positive cells have generally been assumed to be dopaminergic and $\mathrm{TH}$ presence has been used as the classic
We also used an engineered mouse that expressed cre recombinase driven by the TH promoter; microinjections of AAV expressing a cre-dependent ChIEF-tdTomato were made into the ARC. An analysis of staining showed that $85.1 \pm 4.4 \%$ of 259 tdTomatopositive neurons were immunopositive for $\mathrm{TH}$ and $56.9 \pm 7.3 \%$ of $389 \mathrm{TH}$-immunostained neurons were tdTomato-positive, based on 9 sections from two 2-month-old female mice. These data indicate most ChIEF-tdTomato-expressing neurons were $\mathrm{TH}$-positive in the ARC (Fig. 1E). However, AAV injection did not generate ChIEF expression in all TH neurons in the ARC, as would be expected from small injection volumes.

In the present paper, we focus on the dopamine cells of the dmARC using TH-tdTomato reporter expression where our data above strongly support the dopaminergic phenotype of the TH cells. Neurons studied electrophysiologically below expressed the $\mathrm{TH}$ promoter-dependent reporter gene, $94 \%$ of which also contain dopamine in the dmARC. 


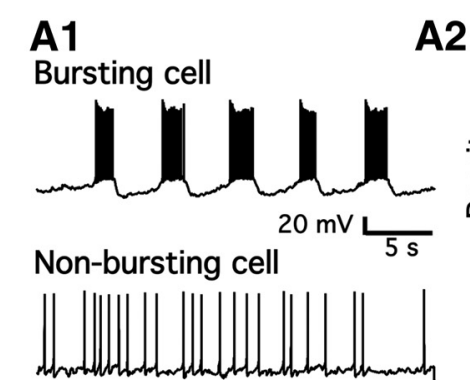

B
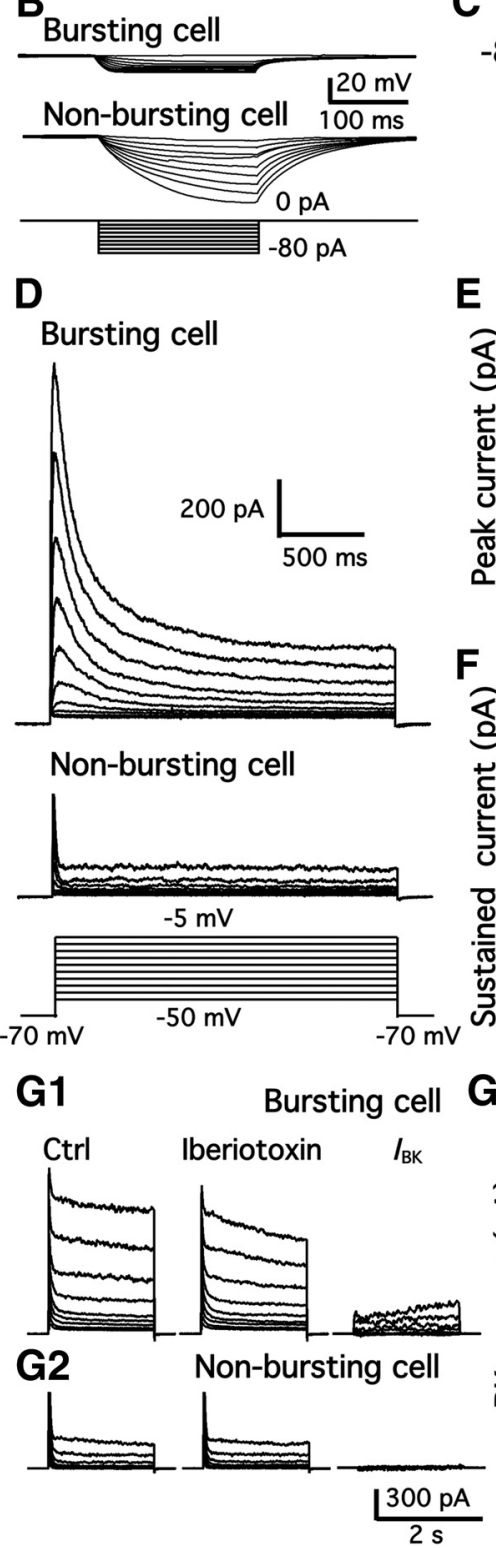

G3

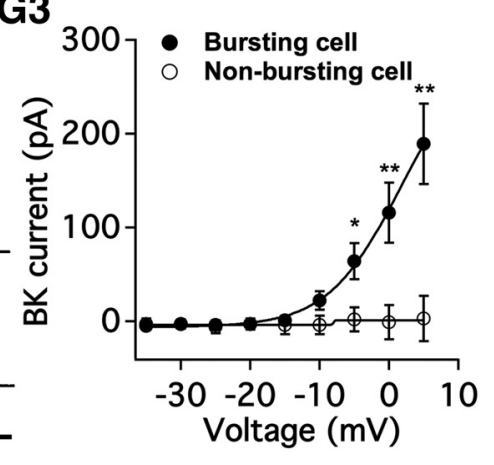

Figure 3. Electrophysiological characterization of two populations of arcuate TH neurons. $\boldsymbol{A}$, Representative traces showing burst firing $\left(\boldsymbol{A 1}\right.$, top) and nonburst firing $\left(\boldsymbol{A} \mathbf{1}\right.$, bottom) of dmARC TH neurons and histogram of $\log _{10}$ ISI of action potentials from bursting (A2) and nonbursting cell (A3). $\boldsymbol{B}$, Membrane potential changes in a bursting neuron (top) and a nonbursting neuron (middle) induced by a series of negative step current injections (bottom). C, Voltage-current relationship for bursting and nonbursting cells obtained from averaged data with recording as in $\boldsymbol{B}$. $\boldsymbol{D}$, Representative traces showing voltage-gated potassium current in bursting and nonbursting neurons at depolarized membrane potentials of -50 to $-5 \mathrm{mV}$ from a holding potential of $-70 \mathrm{mV}$. TTX, $\mathrm{Cd}^{2+}$, Bic, AP5, and CNQX were added to the recording solution to block voltage-gated sodium and calcium channels and synaptic responses. $\boldsymbol{E}$, Summary data showing the peak amplitude of outward potassium current in both types of neuron at various voltages. ${ }^{*} p<0.05$ (Student's $t$ test compared with peak current of nonbursting cells at same voltage). ${ }^{* * *} p<$ 0.001 (Student's $t$ test compared with peak current of nonbursting cells at same voltage). $\boldsymbol{F}$, Summary data showing the amplitude of sustained outward potassium current in both types of neuron at various voltages. ${ }^{*} p<0.05$ (Student's $t$ test compared with
Electrophysiological characteristics of TH neurons in the arcuate nucleus We first studied the electrophysiological characteristics of ARC TH-positive neurons with patch-clamp recording. Based on whole-cell recording from a large number (599 neurons: 483 in dmARC and 116 in vlARC) of tdTomato-expressing neurons, we identified two types of cells displaying differences in membrane properties and anatomical distribution. Most (68\%; $n=330$ of 483) $\mathrm{TH}$ neurons in the dmARC were spontaneously active with regular bursts (Fig. 3A1, top) characterized by $10-30$ spikes occurring over $2-5 \mathrm{~s}$, followed by a silent period ranging from 5-30 s. In the remaining 153 nonbursting dmARC TH neurons (Fig. 3A1, bottom), 69 neurons $(14 \%, 69$ of 483 cells) were silent and 84 neurons $(17 \%, 84$ of 483 cells) were active without bursting. The resting membrane potential for bursting cells was $-74.1 \pm 1.9 \mathrm{mV}(n=30)$, which was significantly more negative than that for nonbursting cells $(-63.7 \pm 2.0 \mathrm{mV}, n=25$, $p<0.05$, one-way ANOVA). The interspike interval (ISI) was compared in bursting and nonbursting neurons. The histograms of $\log _{10}^{\text {ISI }}$ of bursting neurons showed a bimodal distribution with one peak at $\sim 2$ and another peak at $\sim 4$, indicating that the ISI of most spikes during bursting was $\sim 100 \mathrm{~ms}$ and the burst interval was $\sim 10 \mathrm{~s}$ (Fig. $3 A 2$, 2296 spikes from 15 bursting cells). In contrast, the histogram of $\log _{10}^{\text {ISI }}$ of nonbursting cells showed a relatively even monomodal distribution with a peak at $\sim 2.5$, indicating that the ISI of most spikes was $\sim 300 \mathrm{~ms}$ (Fig. 3A3, 2201 spikes from 12 nonbursting cells). We tested the input resistance of the two types of TH neurons through the linear relationship of voltage-current obtained by

\section{$\leftarrow$}

sustained current of nonbursting cells at same voltage). ${ }^{* *} p<0.01$. ${ }^{* * *} p<0.001$. G1, Representative traces show voltage-gated potassium current in a bursting neuron using voltage steps from a holding potential of $-70 \mathrm{mV}$ to a level of -35 to $5 \mathrm{mV}$. Data from control (left) and in the presence of iberiotoxin ( $200 \mathrm{~nm}$, middle) are shown. BK current (right) was obtained by subtraction of potassium current in the presence of iberiotoxin from control. TTX, Bic, AP5, and CNQX were added to the recording solution to block voltage-gated sodium channels and synaptic responses. G2, Representative traces show voltage-gated potassium current in a nonbursting neuron using voltage steps from a holding potential of $-70 \mathrm{mV}$ to a level of -35 to $5 \mathrm{mV}$ in a nonbursting neuron in control (left) and in the presence of iberiotoxin ( $200 \mathrm{~nm}$, middle). No obvious BK current (right) was obtained by subtraction of potassium current in the presence of iberiotoxin from control. G3, Summary data showing the peak amplitude of BK current in both types of neuron at various voltages. ${ }^{*} p<0.05$ (Student's t test compared with $I_{\text {BK }}$ of nonbursting cells at same voltage). ${ }^{* *} p<0.01$. 
Table 1. Similar bursting characteristics of dmARC TH neurons in male and female mice at different stages of development

\begin{tabular}{llllll}
\hline Age (weeks) & Sex & Bursting cell (\%) & Bursting rate (Hz) & Firing rate of single burst (Hz) & Single burst 0N duration (s) \\
\hline $2-4$ & Male & $63.6(126 / 198)$ & $0.079 \pm 0.006(n=27)$ & $3.85 \pm 0.30(n=27)$ & $4.01 \pm 0.11(n=27)$ \\
$2-4$ & Female & $71.6(204 / 285)$ & $0.077 \pm 0.005(n=27)$ & $4.51 \pm 0.52(n=27)$ & $3.94 \pm 0.23(n=27)$ \\
$2-4($ (BX) & Male & $66.7(16 / 24)$ & $0.079 \pm 0.006(n=12)$ & $4.39 \pm 0.36(n=12)$ & $3.37 \pm 0.44(n=12)$ \\
$2-4($ (BX) & Female & $66.7(6 / 9)$ & $0.076 \pm 0.014(n=6)$ & $3.73 \pm 0.44(n=6)$ & $4.23 \pm 0.23(n=6)$ \\
$2-4(18 \beta-G A)$ & Male & $72.7(16 / 22)$ & $0.074 \pm 0.006(n=13)$ & $4.62 \pm 0.45(n=13)$ & $3.45 \pm 0.31(n=13)$ \\
$8-12$ & Male & $65.3(32 / 49)$ & $0.085 \pm 0.006(n=14)$ & $4.11 \pm 0.46(n=14)$ & $3.72 \pm 0.24(n=14)$ \\
$8-12$ & Female & $74.1(40 / 54)$ & $0.084 \pm 0.009(n=21)$ & $3.96 \pm 0.28(n=21)$ & $3.90 \pm 0.31(n=21)$ \\
\hline
\end{tabular}

A Cell-attached recording
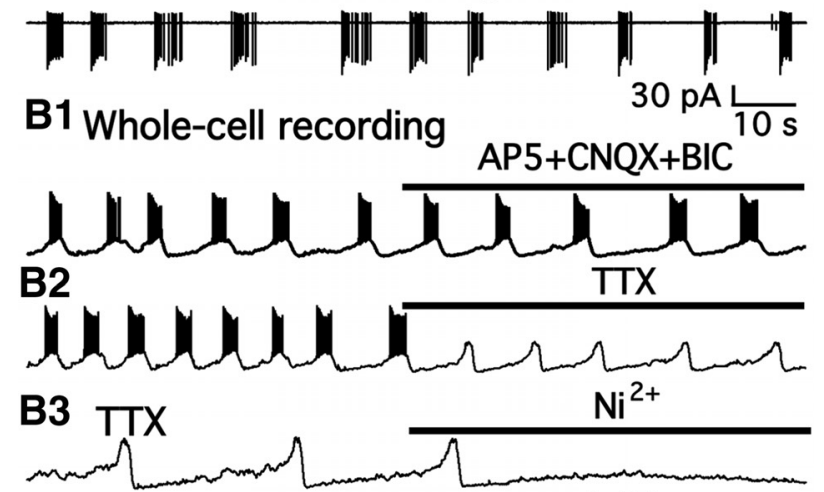

\section{B4}

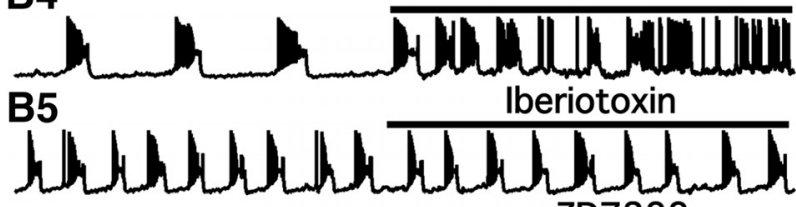

B6

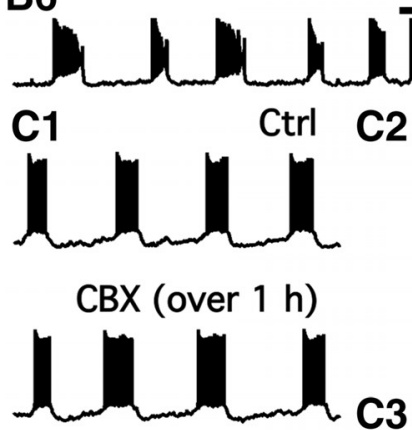

18ß-GA (over $1 \mathrm{~h}$ )

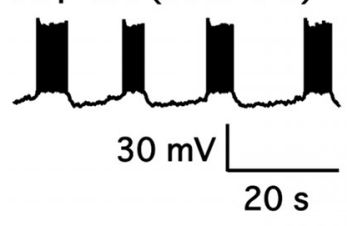

C3

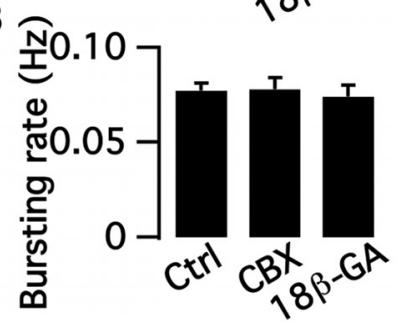

Figure 4. Mechanism of bursting activity. $A$, Regular burst firing recorded in the cellattached mode from a dmARC TH neuron. $\boldsymbol{B 1}$, Regular burst firing recorded in the whole-cell current-clamp configuration was not obviously affected by a mixture of Bic, CNQX, and AP5. B2, TTX blocked firing but not the regular oscillations of the membrane potential. $\boldsymbol{B} 3$, Membrane potential oscillations were blocked by $\mathrm{Ni}^{2+}$ in the presence of TTX. B4, Regular bursting was changed to irregular bursting with shorter burst duration by 4-AP. B5, Burst firing recorded in normal ACSF and in the presence of the BK channel blocker iberiotoxin. B6, Burst firing recorded in normal ACSF and in the presence of $\mathrm{I}_{\mathrm{h}}$ current blocker ZD7288. C1, Representative traces of burst firing recorded in normal ACSF (top) and in the presence of CBX (over $1 \mathrm{~h}$, middle) and $18 \beta$-GA (over $1 \mathrm{~h}$, bottom). $\mathbf{C}$, Percentage of bursting cells in control buffer and in the presence of CBX and $18 \beta-$ GA. C3, The mean burst rate in control and in the presence of $\mathrm{CBX}$ and $18 \beta-\mathrm{GA}$. a series of negative current steps from -80 to $0 \mathrm{mV}$ (Fig. 3B). The input resistance of bursting and nonbursting neurons was substantially different $(p<0.05), 595 \pm 38 \mathrm{M} \Omega$ and $1560 \pm 57 \mathrm{M} \Omega$, respectively (Fig. $3 B, C$ ). We also compared membrane properties of TH neurons in males and females but found little difference between males and nonlactating females, as summarized in Table 1. These data are consistent with a recent report (Romanò et al., 2013).

In the vlARC, only a small percentage of the tdTomato cells show burst firing ( $14 \% ; n=16$ of 116 cells) ( $p<0.001$ compared with percentage of bursting neurons in dmARC); the remaining 100 vlARC cells were silent ( $31 \%, 36$ of 116 cells) or fired without bursts (55\%, 64 of 116 cells). These data suggest that the ventrolateral cells as a group have substantively different properties than the dorsomedial cells, consistent with our immunostaining showing that only a minority of these vlARC TH-positive cells contained dopamine.

Based on these findings, and unless noted otherwise, all data below are based on recordings from the dmARC.

We next examined which types of ion channels contribute to the burst firing in the dmARC. Voltage-gated $\mathrm{K}^{+}$currents were tested in both bursting and nonbursting tdTomato neurons with $2 \mathrm{~s}$ voltage steps from $-50 \mathrm{mV}$ to $-5 \mathrm{mV}$ from a holding potential of $-70 \mathrm{mV}$ (Fig. 3D). The rapidly inactivating component of the current appeared to be an A-type $\mathrm{K}^{+}$current, whereas the sustained current mainly represented delayed rectifier $\mathrm{K}^{+}$current. The peak current of the rapidly inactivating component of the A-type $\mathrm{K}^{+}$current was significantly larger in bursting $\mathrm{TH}$ neurons than in nonbursting neurons (Fig. 3E). The peak A-type current at $-10 \mathrm{mV}$ was $817 \pm 62 \mathrm{pA}$ $(n=15$; Fig. $3 E)$ in bursting TH neurons, whereas it was only $195 \pm$ $34 \mathrm{pA}(n=6$; Fig. $3 E)$ in nonbursting neurons. The sustained currents at various voltage steps were larger in bursting neurons than in nonbursting neurons (Fig. $3 F$ ). The noninactivating steady current at $-10 \mathrm{mV}$ was $199 \pm 11 \mathrm{pA}(n=15$; Fig. $3 F)$ in bursting neurons, whereas it was $94 \pm 22 \mathrm{pA}(n=6$; Fig. $3 F)$ in nonbursting neurons $(p<0.05)$. Therefore, both the A-type and delayed rectifier $\mathrm{K}^{+}$ channel currents were significantly greater in bursting neurons. At membrane potentials close to the spike threshold, A-type $\mathrm{K}^{+}$channel currents were obvious in bursting neurons but not in nonbursting neurons.

We also tested large conductance $\mathrm{Ca}^{2+}$-activated $\mathrm{K}^{+}(\mathrm{BK})$ current and small conductance $\mathrm{Ca}^{2+}$-activated $\mathrm{K}^{+}(\mathrm{SK})$ current in both neuron types. The selective BK channel blocker iberiotoxin (200 nM) inhibited sustained potassium currents at voltages positive to $-10 \mathrm{mV}$, indicating a contribution of BK currents in the sustained potassium current of bursting neurons. However, we did not observe obvious BK currents in nonbursting cells at similar voltage levels (Fig. $3 G 3 ; n=12$ for bursting cells and $n=7$ for nonbursting cells). Additionally, we tested SK currents in bursting and nonbursting $\mathrm{TH}$ neurons and found no obvious SK current activation in either cell type (data not shown). 

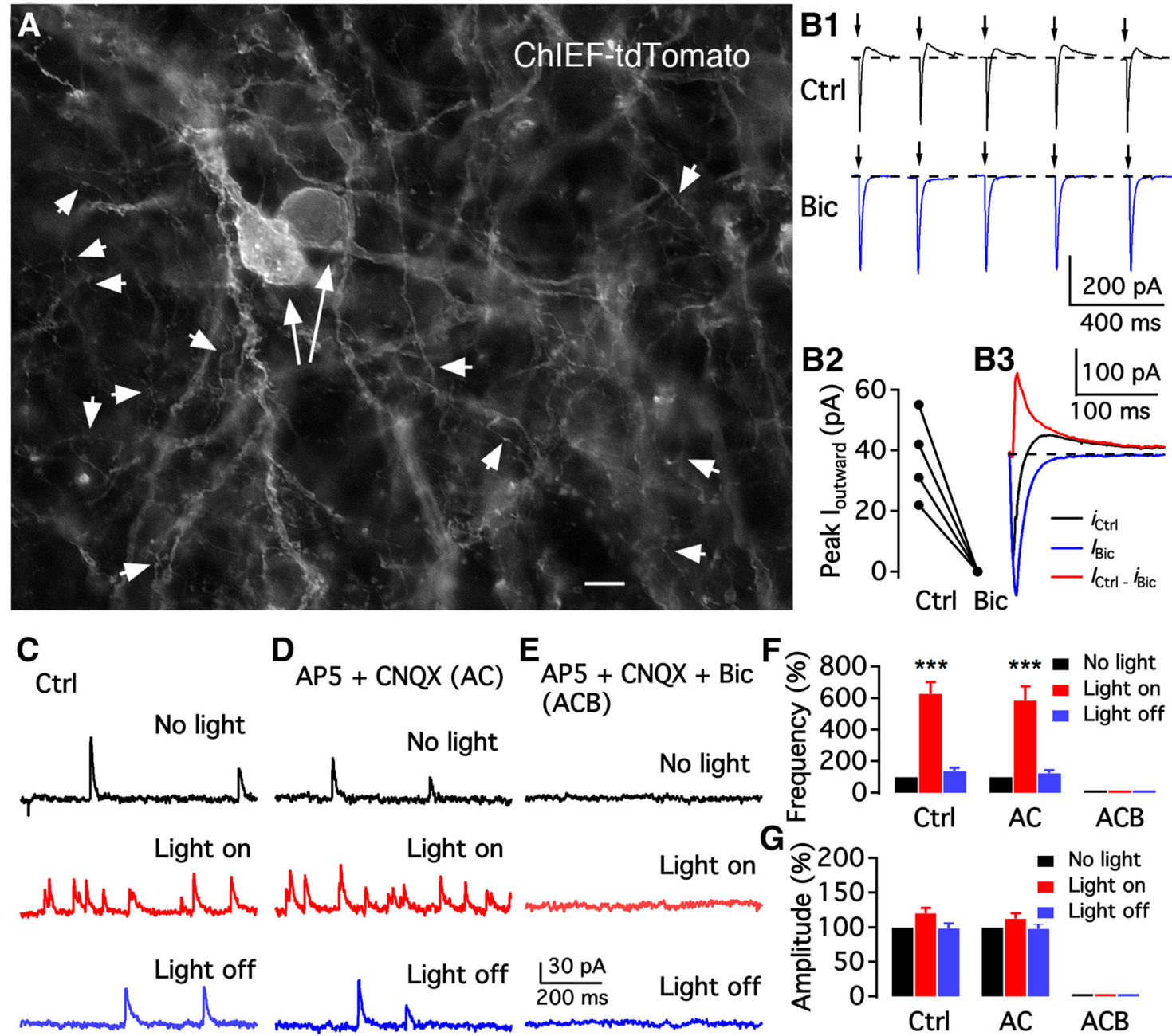

Ctrl AC ACB

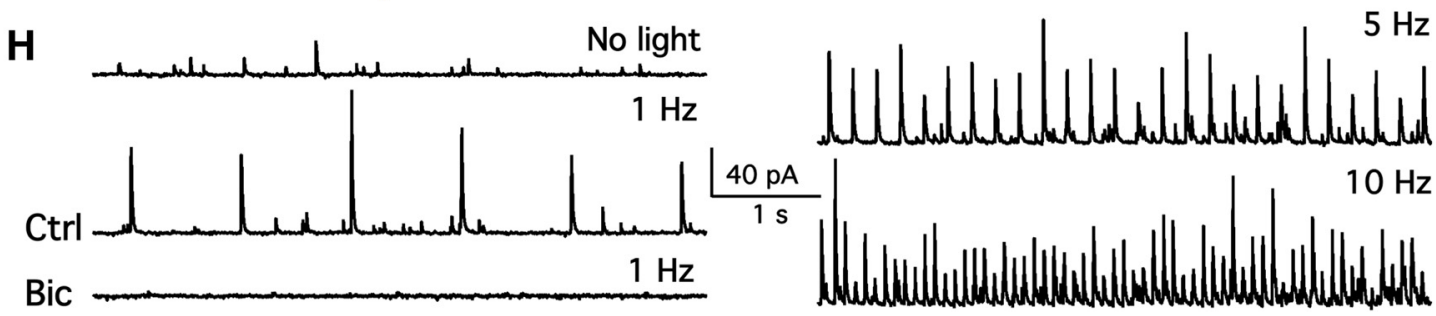

Figure 5. Arcuate TH neurons functionally innervate arcuate neurons. $A$, Photomicrograph shows ChIEF-tdTomato expression in the membrane of dorsomedial ARC of TH-cre mice. Two long arrows indicate positive somata. Short arrowheads indicate very fine positive axonal processes innervating ARC neurons. Scale bar, $7 \mu \mathrm{m}$. $\boldsymbol{B}$, Photostimulation (10 ms) evoked a current with two components in ChlEF-tdTomato-expressing neurons. The membrane potential was held at $-40 \mathrm{mV}$, ensuring an outward current mediated by GABA. B1, Representative traces showing repeated activation using photostimulation (10 ms) of a ChIEF-tdTomato neuron in the absence (Ctrl) and presence of Bic. B2, Mean amplitudes of outward currents evoked by photostimulation in 4 neurons recorded in the absence $(\mathrm{Ctrl})$ and presence of Bic. B3, Mean current traces of five sequential currents induced by photostimulation in the absence (Ctrl) and presence of Bic. The GABA receptor-mediated synaptic current was obtained by subtracting the current in the presence of Bic from the current in the absence of Bic (Ctrl). C-E, Representative traces showing GABAergic IPSCS before light on (top), during light on (middle), and after light off (bottom), in control (Ctrl) solution (C), in the presence of AP5 and CNQX (D), and in the presence of AP5, CNQX, and Bic (E). $F$, Summary of data showing that continuous light stimulation increased IPSC frequency in the absence and presence of AP5 and CNQX, but not in the presence of a mixture of AP5, CNQX, and Bic. ${ }^{* * *} p<0.001$ (one-way ANOVA compared with no light group). G, Bar graph showing that the IPSC amplitude was unaffected by photostimulation. $\boldsymbol{H}$, Representative traces showing spontaneous (top left) and photostimulation (1 Hz)-evoked IPSCs (middle left) recorded from an unidentified arcuate neuron in control and in the presence of Bic (bottom left). Bic inhibited both spontaneous and photostimulation-evoked IPSCs. The frequency of evoked IPSCs increased with photostimulation frequency ( $5 \mathrm{~Hz}$, top right, and $10 \mathrm{~Hz}$, bottom right).

\section{Mechanism of bursting activity}

Here, we address the mechanisms underlying bursting. Using the cell-attached configuration to avoid disturbing the intracellular ionic milieu, we recorded the spontaneous firing of bursting neurons and found a burst frequency of $0.18 \pm 0.02 \mathrm{~Hz}(n=10$; Fig. $4 A)$. With whole-cell current-clamp, the burst frequency was $0.07 \pm 0.004 \mathrm{~Hz}(n=39)$. However, we found no membrane current oscillations or bursting current with whole-cell voltage clamp. The bursting pattern was not obviously affected by synaptic blockade of ionotropic GABA and glutamate receptors with Bic $(30 \mu \mathrm{M})$, D-AP5 $(50 \mu \mathrm{M})$, and CNQX $(10 \mu \mathrm{M})(n=6$; Fig. $4 B 1)$. The $\mathrm{Na}^{+}$channel blocker TTX (1 $\left.\mu \mathrm{M}\right)$ blocked action potential firing, but not the regular membrane potential oscillation ( $n=10$; Fig. 4B2). These data suggest that the bursting is an intrinsic property of the cells and is not dependent on synaptic activity. 

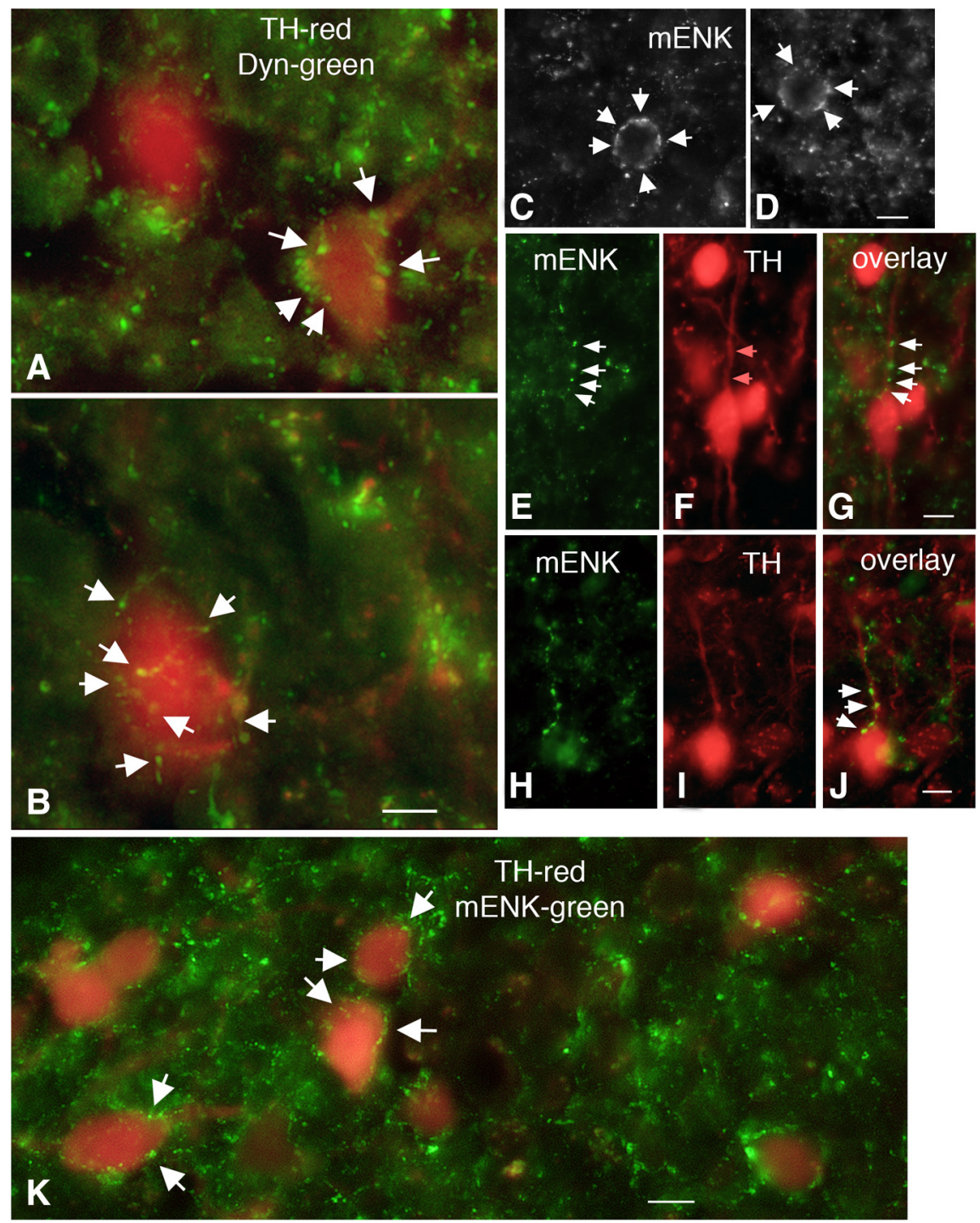

Figure 6. Dyn and $m$-ENK-immunoreactive axons contact arcuate TH neurons. $A, B$, Merged images showing TH neurons (red) surrounded by Dyn axons (green). Scale bar, $10 \mu \mathrm{m}$. $\boldsymbol{C}, \boldsymbol{D}$, Merged images showing TH neuron somata surrounded by mENK axons (white arrows). Scale bar, $10 \mu \mathrm{m}$. $\boldsymbol{E}-\boldsymbol{J}$, Representative images showing mENK axons $(\boldsymbol{E}, \boldsymbol{H})$, TH-tdTomato neurons $(\boldsymbol{F}, \boldsymbol{I})$, and the overlay (G,J). Scale bar, $10 \mu \mathrm{m}$. $\boldsymbol{K}$, Merged image showing TH neurons (red) surrounded by mENK axons (green). Scale bar, $10 \mu \mathrm{m}$.

We next tested the effect of the broad-spectrum $\mathrm{Ca}^{2+}$ channel blocker $\mathrm{Cd}^{2+}$ and the selective T-type $\mathrm{Ca}^{2+}$ channel blocker $\mathrm{Ni}^{2+}$ on the membrane potential oscillations. Both $\mathrm{Cd}^{2+}(100 \mu \mathrm{M}$; data not shown) and $\mathrm{Ni}^{2+}(100 \mu \mathrm{M})$ abolished the membrane potential oscillations in the presence of TTX ( $1 \mu \mathrm{M} ; n=5$; Fig. $4 B 3)$. These data together suggest that T-type $\mathrm{Ca}^{2+}$ channels contribute to the initiation of membrane depolarization and the subsequent bursting of TH neurons. Based on the data above showing that bursting neurons have significant A-type $\mathrm{K}^{+}$currents, we tested the effect of the A-type $\mathrm{K}^{+}$channel blocker 4-AP on the bursting activity. 4-AP (2 $\mathrm{mM})$ changed the regular oscillations to irregular bursting $(n=6$; Fig. 4B4), corroborating the view that A-type $\mathrm{K}^{+}$channels contribute to the regular bursting of these ARC TH neurons. Although BK currents contributed to the sustained potassium current shown above, no obvious effect was observed on bursting neuron oscillations by the selective BK channel blocker iberiotoxin (200 nM; Fig. 4B5). Hyperpolarization-activated cation currents ( $\mathrm{I}_{\mathrm{h}}$ current) may contribute to rhythmic oscillations in membrane potential in some types of neurons (Pape, 1996; Lüthi et al., 1998). However, we did not detect substantial $\mathrm{I}_{\mathrm{h}}$ current in bursting neurons, and the selective $\mathrm{I}_{\mathrm{h}}$ current blocker ZD7288 $(10 \mu \mathrm{M})$ produced little effect on membrane potential oscillation (Fig. 4B6).

A previous study showed that gap junctions play an essential role in the burst firing of rat ARC dopamine neurons (Lyons et al., 2010). We therefore tested the effect of the gap junction blocker CBX $(100 \mu \mathrm{M})$ (Sharifullina et al., 2008; Meme et al., 2009; Vivar et al., 2012) on the burst pattern in mouse brain slices. The bursting rate was $0.07 \pm 0.01 \mathrm{~Hz}(n=6)$ in control and $0.07 \pm 0.01 \mathrm{~Hz}(n=6)$ after $10 \mathrm{~min}$ treatment of CBX $(100 \mu \mathrm{M})$. Thus, in contrast to the rat, our data showed no obvious effect of CBX on burst firing in bursting dopamine neurons in the ARC of the mouse even at twice the concentration of the gap junction blocker used by Lyons et al. (2010). We tested further the effect of long application of CBX and $18 \beta-\mathrm{GA}$, another gap junction blocker, on the burst pattern in mouse brain slices. Brain slices were incubated with CBX $(100 \mu \mathrm{M})$ or $18 \beta-\mathrm{GA}(50 \mu \mathrm{M})$ for $>1$ h before recording to ensure sufficient time for effective blockade of gap junctions. The percentage of bursting cells was $68.1 \%$ (310 of 455), $64.3 \%$ (9 of 14 ), and $78.6 \%$ (11 of 14 ) in control, CBX and 18 $\beta-$ GA, respectively (Fig. $4 C 2$ ). No obvious inhibition of CBX and $18 \beta$-GA was observed on the percent of bursting dmARC TH neurons. The burst rate was $0.07 \pm 0.004 \mathrm{~Hz}(n=39)$, $0.08 \pm 0.01 \mathrm{~Hz}(n=9)$, and $0.08 \pm 0.01$ $\mathrm{Hz}(n=8)$ in control, CBX, and $18 \beta$ GA, respectively (Fig. 4C1,C3). In addition, the firing rate of single bursts of dmARC TH neurons from female mice was $4.5 \pm 0.5 \mathrm{~Hz}(n=27)$ and $3.7 \pm 0.4$ $\mathrm{Hz}(n=6)$ in control and in the presence of CBX, respectively (Table 1). The single "burst ON" duration was $3.9 \pm 0.2 \mathrm{~s}(n=27)$ and $4.2 \pm 0.2(n=6)$ in control and in the presence of CBX, respectively (Table 1 ). These results indicated that the bursting characteristics were not obviously changed by CBX.

These data showed no detectable effect of CBX and $18 \beta-\mathrm{GA}$ on the bursting rate of dmARC TH neurons in mouse. Together, our results suggest that bursting in mouse ARC TH neurons does not appear to be dependent on gap junctions.

\section{Arcuate TH neurons innervate arcuate neurons and release GABA synaptically}

To date, the focus on the axons of ARC dopamine neurons has been on the projections to the median eminence where dopamine is released into the circulatory system, as underlined by the use of the tuberoinfundibular dopamine neuron nomenclature. Whether these cells send projections elsewhere either has not been studied or the projections have been assumed to be nonexistent (Jonsson et al., 1972; Everitt et al., 1984). ARC dopamine 


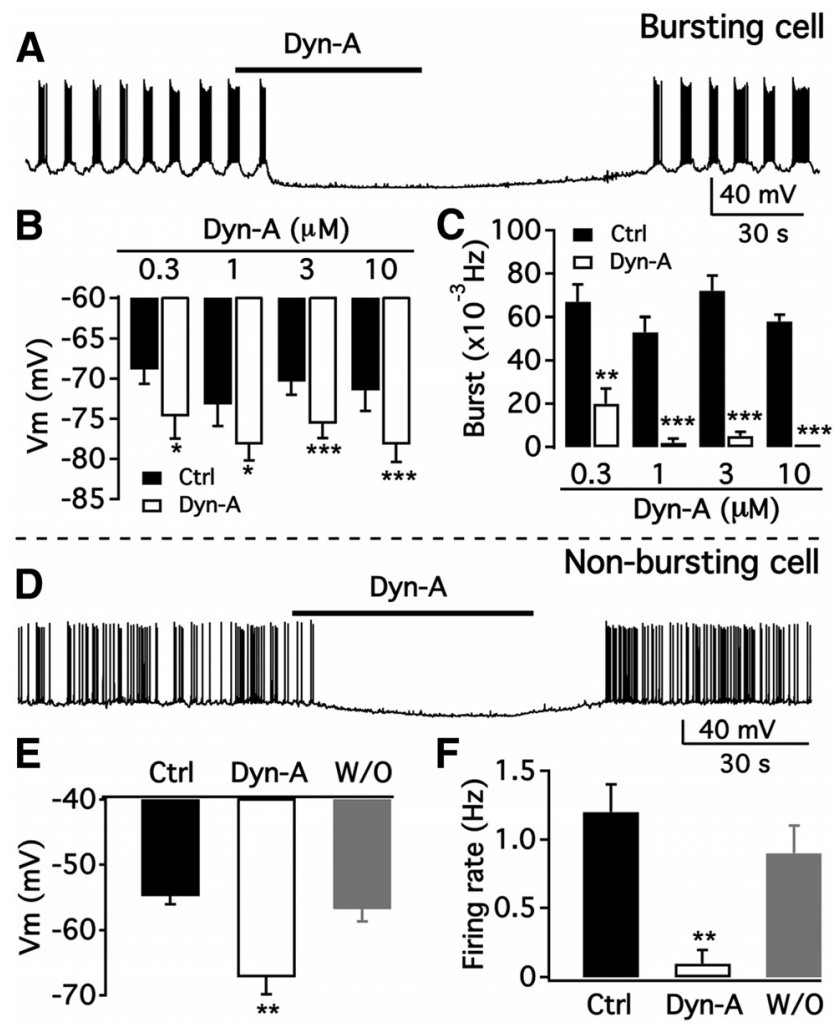

Figure 7. Selective inhibition of dorsomedial ARC TH neurons by Dyn. $A$, Dyn-A $(3 \mu \mathrm{M})$ completely abolished dmARC neuron bursting. $\boldsymbol{B}$, Bar graph showing dose-dependent effect of Dyn-A on the membrane potential of dmARC bursting neurons. ${ }^{*} p<0.05$ (paired $t$ test compared with control without Dyn-A treatment). ${ }^{* *} p<0.001$. C, Dose-dependent effect of Dyn-A on the burst frequency of dmARC neurons. ${ }^{* *} p<0.01 .{ }^{* *} p<0.001$ (paired $t$ test compared with control without Dyn-A treatment). $\boldsymbol{D}$, Representative trace showing Dyn-A inhibition of a dmARC nonbursting neuron. $\boldsymbol{E}$, Bar graph showing the mean Dyn-A effect on the membrane potential of nonbursting neurons before Dyn-A treatment (Ctrl), during Dyn- $A$ treatment, and after washout (W/0) of Dyn-A. ${ }^{* *} p<0.01$ (one-way ANOVA compared with control before Dyn-A treatment). $\boldsymbol{F}$, Bar graph showing the mean Dyn-A effect on the firing rate of nonbursting neurons before Dyn-A, during Dyn-A treatment, and after washout. ${ }^{* *} p<0.01$ (one-way ANOVA compared with control before Dyn-A treatment).

neurons express dopamine receptors (Lin et al., 2000; RomeroFernandez et al., 2014), suggesting that they may respond to dopamine and also synthesize glutamate decarboxylase, the synthetic enzyme for the fast neurotransmitter GABA (Everitt et al., 1984). Although GABA may influence prolactin release in the pituitary (McCann and Rettori, 1986), whether GABA released from ARC TH neurons may play additional roles has not been studied. In addition, the source of dopamine that might modulate ARC TH neuron autoreceptors is not clear.

To address these questions, we used optogenetics using the channelrhodopsin variant, ChIEF (Lin et al., 2009). Small microinjections of Cre-dependent ChIEF-tdTomato-AAV-DJ (Grimm et al., 2008) were made into the ARC of TH-Cre mice to selectively generate Cre-dependent ChIEF expression in $\mathrm{TH}$ neurons (Fig. 1E). A high density of ChIEF-tdTomato was found in axons of the median eminence and in axons and neurons of the ARC. Within the ARC many very fine labeled axons with terminal and en passant boutons were noted (Fig. 5A), consistent with our dopamine immunostaining that also showed fine axons that appeared to abut ARC neurons (Fig. $2 F$ ). No expression of ChIEFtdTomato in other catchecholamine cell groups from more caudal brain was detected. To test optogenetic activation of ARC TH neurons expressing ChIEF-tdTomato, the currents induced by a series of 5 light pulses of $10 \mathrm{~ms}$ duration were recorded in ChIEF-dTomato-expressing neurons. Each light pulse induced an inward current of large amplitude with fast decay followed by an outward current of small amplitude with slow decay $(n=7$ neurons; Fig. 5B1, top traces). In contrast, light pulses of long wave length light evoked no obvious current, consistent with the view that the optogenetic stimulation stimulates ChIEFexpressing cells with blue light. The $\mathrm{GABA}_{\mathrm{A}}$ receptor antagonist Bic completely blocked the outward currents evoked by photostimulation ( $n=4$; Fig. 5B1,B2). The light-evoked current was a mixture of currents that included both direct light-activated ChIEF-mediated inward (excitatory) current and indirect synaptically mediated outward (inhibitory) current. To determine the net outward current mediated by $\mathrm{GABA}_{\mathrm{A}}$ receptors, we averaged the currents induced by 5 light pulses in the absence $\left(I_{\mathrm{Ctrl}}\right)$ or presence of Bic $\left(I_{\mathrm{Bic}}\right)$. The net $\mathrm{GABA}_{\mathrm{A}}$ receptor-mediated current was determined by subtracting $I_{\mathrm{Bic}}$ from $I_{\mathrm{Ctrl}}$ (Fig. $5 B 3$ ).

We tested the effect of 1 min continuous photostimulation of ARC TH neurons on GABAergic IPSCs. Photostimulation dramatically increased IPSC frequency to $628 \pm 73 \%$ of control $(n=7$; Fig. $5 F)$ recorded in ChIEF/tdTomato-positive neurons. Most (67\%, 24 of 36) TH neurons tested showed an increase in IPSCs upon photostimulation, suggesting a robust set of local collaterals. In the presence of AP5 and CNQX to block glutamate-mediated EPSCs, 1 min photostimulation increased IPSC frequency to $586 \pm 89 \%$ of control (light off) immediately after light stimulation $(n=7$; Fig. $5 F)$. No significant change was observed in IPSC amplitude before and during photostimulation in the absence or presence of AP5 and CNQX (Fig. 5G), suggesting that the synaptic currents were not mediated by glutamate. Bic completely blocked IPSCs before and during photostimulation ( $n=7$; Fig. $5 F)$, suggesting the release of GABA.

We next examined the effect of TH neuron activation on other unidentified ARC neurons. Photostimulaton ( $5 \mathrm{~ms}, 1,5$, and $10 \mathrm{~Hz}$ ) of neurons or axons expressing ChIEF/tdTomato activated strong outward phase-locked postsynaptic currents in the majority of cells tested in dmARC ( $64 \%, 28$ of 44 cells) unidentified ARC neurons held at a potential of $-40 \mathrm{mV}$ (Fig. $5 H)$. The outward currents were completely blocked by Bic, indicating that $\mathrm{TH}$ neuron activation by photostimulation evoked $\mathrm{GABA}$ release that activated $\mathrm{GABA}_{\mathrm{A}}$ receptors on postsynaptic ARC neurons. These results together suggest that ARC TH neurons functionally innervate each other and also innervate other ARC neurons and release GABA onto postsynaptic target neurons. Both dmARC and vlARC neurons were recorded, and both groups showed synaptic inhibition during optogenetic stimulation.

\section{Neuropeptide modulation of ARC TH neurons}

Below we studied the effects of three neuropeptides that have been reported to modulate prolactin release to (1) test the hypothesis that the different populations of dmARC TH cells may respond differently to neuromodulators, and (2) to test the hypothesis that these neuromodulators might act by regulating the activity of TH cells that control prolactin release. Previous work has shown that the electrophysiological characteristics and responses of dopamine cells are similar in lactating females and nonlactating females and males (Romanò et al., 2013) and that another neuropeptide, thyrotropin-releasing hormone, that influences prolactin and milk synthesis, has a strong effect on ARC TH neurons (Lyons et al., 2010). The studies below focus on TH-tdTomato-positive ARC neurons to study the actions of the 
A

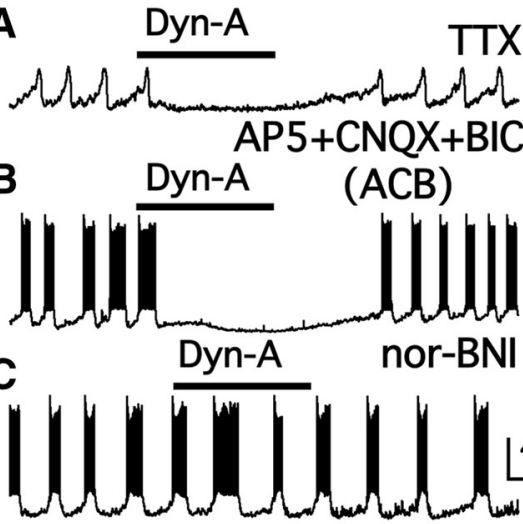

E

Ctrl

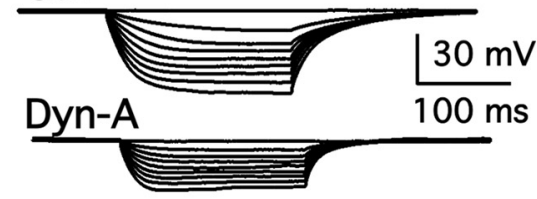

D

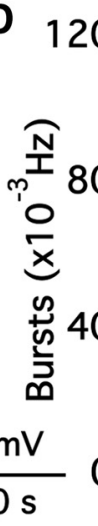

$F$ Current $(\mathrm{pA})$
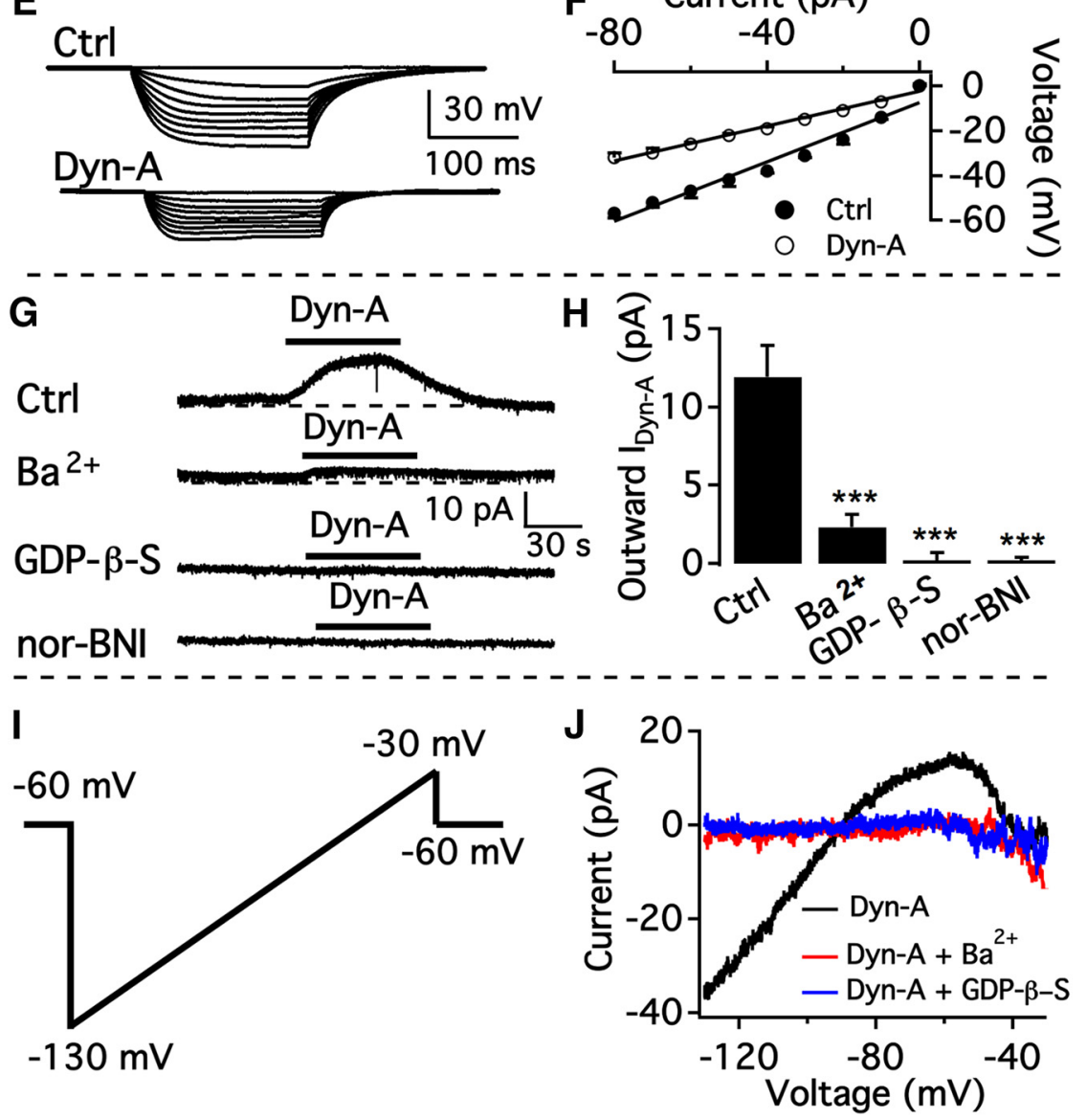

Figure 8. Dyn-A activates GIRK current mediated by $\kappa$ opioid receptors. $A$, Dyn-A $(3 \mu \mathrm{M})$ inhibited membrane potential oscillations in dmARC TH neurons in the presence of TTX. $B$, Dyn-A inhibited burst firing in dmARC neurons in the presence of AP5, CNQX, and Bic. C, Lack of effect of Dyn-A on burst firing of dmARC neuron in the presence of the $\kappa$ opioid receptor antagonist nor-BNI (100 nm). D, Bar graph showing the summary of Dyn-A effects on burst frequency of dmARC neurons in different conditions. ${ }^{* *} p<0.001$ (paired $t$ test compared with control before Dyn-A treatment). E, Representative traces showing the response of a bursting neuron to current injection from -80 to $0 \mathrm{pA}$ before (top) and during (bottom) application of Dyn-A in the presence of TTX, AP5, CNQX, and Bic. $F$, Voltage - current relationship of the averaged responses to current injection before and during Dyn-A application in 6 cells. G, Dyn-A (3 $\mu \mathrm{M})$ activated current in the presence of TTX, AP5, CNQX, and Bic was blocked by Ba ${ }^{2+}$, GDP- $\beta$-S, or nor-BNI. $\boldsymbol{H}$, Bar graph showing the average Dyn-A-activated current in the absence (Ctrl) and presence of various blockers. ${ }^{* * *} p<0.001$ (one-way ANOVA compared with control group). $I$, Voltage ramp protocol from -130 to $-30 \mathrm{mV}$ in $800 \mathrm{msec}$ used to activate GIRK current. J, Dyn-A-activated current at voltages ranging from -130 to $-30 \mathrm{mV}$. The current was blocked by $\mathrm{Ba}^{2+}$ or GDP- $\beta$-S.

three hypothalamic neuropeptides that have been reported to modulate prolactin levels, including Dyn, m-ENK, and oxytocin (Kiem et al., 1988; Butelman et al., 1999; Kennett and McKee, 2012).

Ctrl Dyn-A

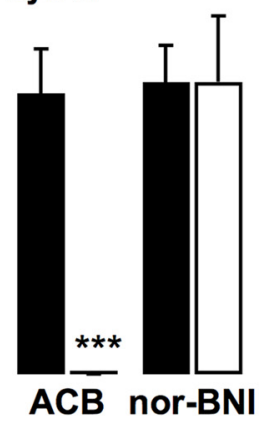

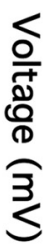

Dyn and m-ENK-immunoreactive axons terminate on arcuate dopamine neurons The endogenous opioids Dyn and m-ENK are two hypothalamic neuropeptides that stimulate prolactin release (Andrews and Grattan, 2003) by an unknown mechanism. Here, we examined whether Dyn and m-ENK-immunoreactive axons terminate on dmARC TH/dopamine neurons. We previously described Dyn axons within the ARC (Zhang and van den Pol, 2013). To determine whether Dyn neurons innervate ARC TH neurons, we combined green immunofluorescence with detection of tdTomato fluorescence in TH-tdTomato neurons. A large number of Dynimmunoreactive axons were found terminating near or on dmARC TH neurons (Fig. $6 A, B)$. Similarly, a high density of mENKimmunoreactive axons was also found in the ARC (Fig. 6C-K). Many mENK axons had terminal boutons in apparent contact with the cell body and also dendrites of $\mathrm{TH}$ neurons.

Dyn-A selectively inhibited dorsomedial ARC dopamine neurons

Dyn-A dose-dependently hyperpolarized the bursting $\mathrm{TH}$ neurons and inhibited the burst firing (Fig. 7A-C). Dyn-A (3 $\mu \mathrm{M})$ hyperpolarized the membrane potential from $-70.9 \pm 1.7 \mathrm{mV}$ to $-75.9 \pm$ $1.8 \mathrm{mV}(n=19$; Fig. $7 B)$ and decreased the burst frequency from $0.071 \pm 0.007$ $\mathrm{Hz}$ to $0.005 \pm 0.003 \mathrm{~Hz}(n=19$; Fig. $7 C)$.

The effect of Dyn-A on the activity of nonbursting $\mathrm{TH}$ neurons in the dmARC was also tested. Dyn-A ( $3 \mu \mathrm{M})$ hyperpolarized the membrane potential from $-54.8 \pm$ $1.3 \mathrm{mV}$ to $-67.2 \pm 2.6 \mathrm{mV}(n=9$; Fig. $7 E)$ and decreased firing rate from $1.2 \pm 0.2 \mathrm{~Hz}$ to $0.1 \pm 0.1 \mathrm{~Hz}(n=7$; Fig. $7 F)$.

We also tested the effect of Dyn-A on the activity of nonbursting $\mathrm{TH}$ neurons in the vlARC. In contrast to the dmARC neurons, Dyn-A $(3 \mu \mathrm{M})$ had no effect on the membrane potential or the firing rate of vlARC nonbursting tdTomato-positive neurons. The membrane potential was $-53.5 \pm 0.8$ $\mathrm{mV}$ and $-54.7 \pm 1.0 \mathrm{mV}$ in the absence and in the presence of Dyn-A, respectively ( $n=$ 15). The firing rate was $1.3 \pm 0.2 \mathrm{~Hz}$ in the absence and $1.4 \pm 0.3 \mathrm{~Hz}$ in the presence of Dyn-A $(n=12)$.

\section{Mechanism of Dyn-A inhibition}

To examine the mechanism of Dyn-A inhibition, the effect of Dyn-A on dmARC TH neuron oscillations was tested in the presence of TTX. TTX (1 $\mu \mathrm{M})$ abolished action potentials but showed little effect on regular membrane potential oscillations $(n=6$; Fig. $8 A, D)$. The oscillation frequency was $0.08 \pm 0.01$ $\mathrm{Hz}$ in the absence of Dyn-A, and the oscillations were com- 
pletely inhibited by Dyn-A ( $3 \mu \mathrm{M})$. In addition, in the presence of AP5, CNQX, and Bic to block glutamate and GABA ionotropic receptors, the bursting frequency was $0.077 \pm 0.012 \mathrm{~Hz}$ and was completely inhibited by Dyn-A (3 $\mu \mathrm{M})(n=6$; Fig. $8 B, D)$, suggesting that the Dyn effect was direct and not synaptically mediated. In the presence of a low concentration of nor-BNI (100 nM), a selective $\kappa$ opioid receptor antagonist, there was no Dyn-A inhibition. The burst frequency was $0.08 \pm 0.01 \mathrm{~Hz}$ in the presence of nor-BNI, which was not significantly different from that during treatment with Dyn-A (3 $\mu \mathrm{M})$ plus norBNI $(n=6$; Fig. $8 D)$, suggesting that Dyn-A acts by direct activation of $\kappa$ opioid receptors. To confirm further that Dyn-A directly opens ion channels in dmARC TH neurons, we investigated the voltage-current relationship evoked by negative current injection in the presence of TTX, AP5, Bic, and CNQX (Fig. $8 E$ ). The input resistance determined from current injection was $665 \pm$ $52 \mathrm{M} \Omega$ before treatment with Dyn-A and was reduced to $390 \pm 17 \mathrm{M} \Omega$ by Dyn-A $(3 \mu \mathrm{M})(n=5$; Fig. $8 F)$. The significant $(p<0.01)$ decrease of input resistance suggests that Dyn-A opens ion channels that contribute to the inhibition of dmARC TH neurons.

To examine whether Dyn-A opens G-protein-coupled inwardly rectifying potassium (GIRK) channels, we tested the effect of GIRK current blockers on Dyn-A currents. In the presence of TTX $(1 \mu \mathrm{M})$, D-AP5 $(50 \mu \mathrm{M})$, CNQX (10 $\mu \mathrm{M})$, and Bic $(30 \mu \mathrm{M})$, Dyn-A evoked an outward current with an amplitude of $11.9 \pm 2.0 \mathrm{pA}$ when the membrane potential was held at $-60 \mathrm{mV}(n=8$; Fig. $8 G, H)$. In the presence of $\mathrm{Ba}^{2+}(800 \mu \mathrm{M})$, a blocker of inwardly rectifying $\mathrm{K}^{+}$channels, the current induced by Dyn-A was decreased to $2.3 \pm 0.8 \mathrm{pA}$ ( $n=5$; Fig. $8 G, H)$. These results indicate that Dyn-A activated inwardly rectifying $\mathrm{K}^{+}$channels. We next used the nonhydrolyzable GDP analog GDP- $\beta$-S instead of GTP in the recording pipette to test whether Dyn-A activation of inwardly rectifying $\mathrm{K}^{+}$channels depends on GTP. After $>5$ min of loading of GDP- $\beta$-S $(2 \mathrm{~mm})$ into the cells, Dyn-A ( $3 \mu \mathrm{M})$ induced no obvious current $(0.2 \pm$ $0.5 \mathrm{pA}$ at $-60 \mathrm{mV}, n=7$; Fig. $8 G, H)$. Nor-BNI used at a concentration $(100 \mathrm{nM}$ ) reported to be selective for $\kappa$ receptors (Pennock and Hentges, 2014) completely blocked any Dyn-A current $(n=$ 7; Fig. $8 G, H)$. We also recorded GIRK currents evoked by Dyn-A $(3 \mu \mathrm{M})$ with a voltage ramp from -130 to $-30 \mathrm{mV}$ (Fig. $8 I$ ) in the presence of blocking agents, including TTX (1 $\mu \mathrm{M})$, D-AP5 (50 $\mu \mathrm{M})$, CNQX $(10 \mu \mathrm{M}), \mathrm{Bic}(30 \mu \mathrm{M})$, and $\mathrm{Cd}^{2+}(200 \mu \mathrm{M})$. Dyn-A evoked an inwardly rectifying current with a reversal potential at $-90.9 \pm 1.5 \mathrm{mV}(n=8$; Fig. $8 \mathrm{~J})$, close to the $\mathrm{K}^{+}$equilibrium potential, suggesting a direct effect on GIRK channels. The cur-
Bursting cell
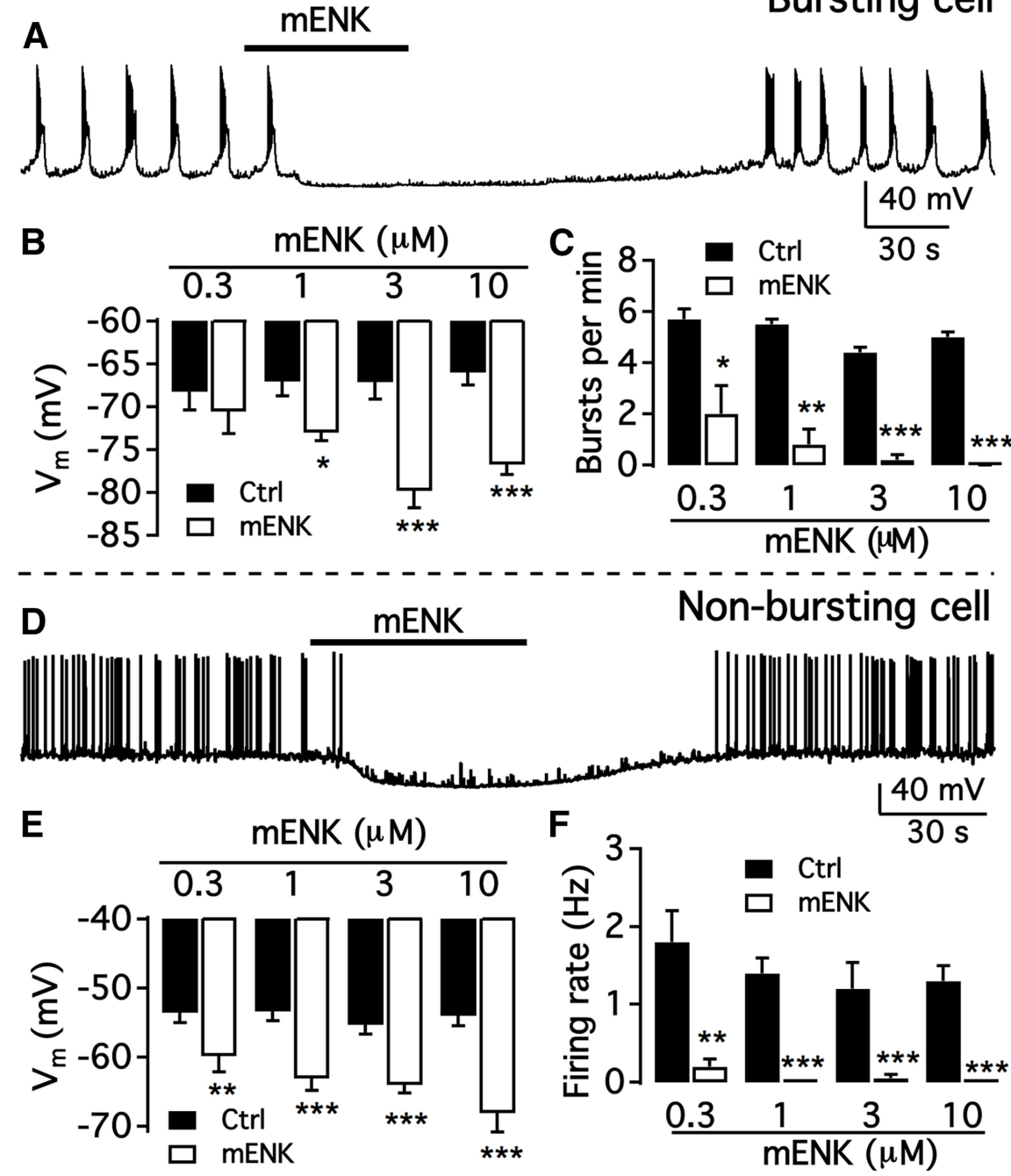

Figure 9. mENK inhibits both types of arcuate TH neurons in a dose-dependent manner. $\boldsymbol{A}$, Representative trace showing mENK (3 $\mu \mathrm{m}$ ) inhibition of a bursting dmARC neuron. $\boldsymbol{B}$, Bar graph showing dose-dependent effect of mENK on the membrane potential f bursting dmARC neurons. ${ }^{*} p<0.05$ (paired $t$ test compared with control without mENK treatment). ${ }^{* * *} p<0.001$. $\boldsymbol{C}$ ${ }^{* *} p<0.01$ (paired $t$ test compared with control without mENK treatment) . ${ }^{* *} p<0.001$ (paired $t$ test compared with control without mENK treatment). $\boldsymbol{F}$, Bar graph showing the mean Dyn-A effect on the firing rate of nonbursting dmARC neurons. ${ }^{* *} p<0.01$ (paired $t$ test compared with control without mENK treatment). ${ }^{* * *} p<0.001$.

rent was abolished by bath application of $\mathrm{Ba}^{2+}(800 \mu \mathrm{M})(n=5$; Fig. $8 J)$ or with GDP- $\beta$-S $(2 \mathrm{~mm})$ in the recording pipette solution $(n=7$; Fig. $8 \mathrm{~J})$, further confirming that Dyn-A activated GIRK currents in dmARC TH neurons.

mENK inhibits bursting and nonbursting TH neurons

To explore whether mENK influences TH neurons, we first studied the effect of mENK on the activity of the bursting dmARC cells. mENK $(3 \mu \mathrm{M})$ significantly hyperpolarized the membrane potential from $-67.1 \pm 2.0 \mathrm{mV}$ to $79.8 \pm 2.2 \mathrm{mV}(p<0.001 ; n=$ 9; Fig. $9 A, B$ ) and completely inhibited burst firing (Fig. 9A, C). The mENK inhibition was dose-dependent and reversible (Fig. $9 A, C)$, similar to the studies above on Dyn.

We then tested the effect of mENK on the activity of nonbursting neurons. Nonbursting TH neurons were strongly inhibited by mENK in a dose-dependent fashion (Fig. 9D). $\operatorname{mENK}(3 \mu \mathrm{M})$ significantly hyperpolarized the membrane potential from $-55.3 \pm 1.4 \mathrm{mV}$ to $-64.0 \pm 1.4 \mathrm{mV}(n=9$; Fig. 

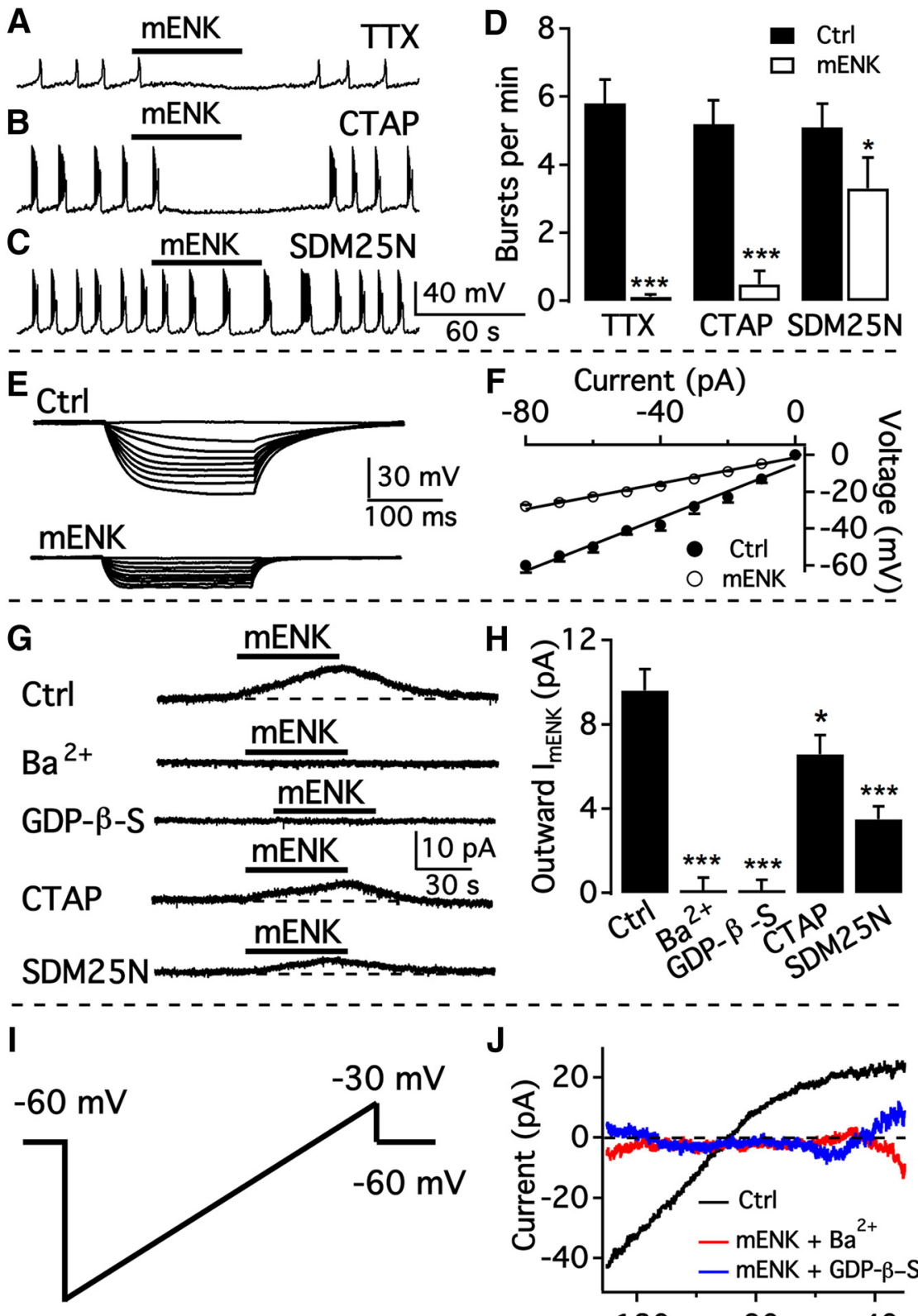

$-130 \mathrm{mV}$

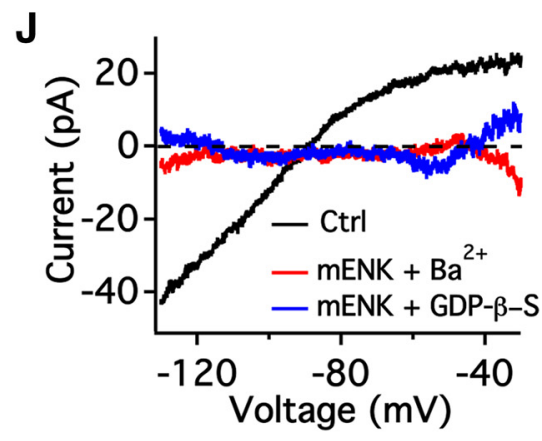

Figure 10. mENK is inhibitory by activating GIRK current mainly mediated by $\delta$ opioid receptors. $\boldsymbol{A}, \mathrm{mENK}$ ( $3 \mu \mathrm{m}$ ) hyperpolarized bursting dopamine neurons and inhibited burst firing in the presence of TTX. $\boldsymbol{B}$, Representative trace showing the effect of mENK on the bursting activity of a dmARC TH neuron in the presence of the $\mu$ opioid receptor antagonist CTAP. $C$, Representative trace showing the effect of mENK on bursting in the presence of the $\delta$ opioid receptor antagonist SDM25N (1 $\mu$ M). D, Bar graph summarizing the effects of mENK on the burst frequency of dorsomedial ARC neurons in the absence and presence of various blockers. ${ }^{*} p<0.05$ (paired $t$ test compared with control before mENK treatment). ${ }^{* * *} p<0.001$ (paired $t$ test compared with control before mENK treatment). $\boldsymbol{E}$, Representative traces showing the response of a bursting $\mathrm{dmARC}$ neuron to current injection from -80 to 0 pA before (top) and during (bottom) application of mENK in the presence of TTX, AP5, CNQX and Bic. $\boldsymbol{F}$, Voltagecurrent relationship of the averaged responses to current injection before and during mENK application from 5 cells. G, mENKactivated current in the presence of TTX, AP5, CNQX, and Bic and its decrease by $\mathrm{Ba}^{2+}$, GDP- $\beta$-S, CTAP, or SDM25N. $\boldsymbol{H}$, Bar graph showing the average current in the absence and in presence of various blockers. ${ }^{*} p<0.05$ (one-way ANOVA compared with control without mENK treatment). ${ }^{* * *} p<0.001$ (one-way ANOVA compared with control without mENK treatment). I, Voltage ramp protocol from -130 to $-30 \mathrm{mV}$ in $800 \mathrm{msec}$ used to activate GIRK current. J, mENK-activated current at voltages from -130 to $-30 \mathrm{mV}$, which was blocked by $\mathrm{Ba}^{2+}$ or GDP- $\beta$-S.

$9 E$ ) and decreased the firing rate from $1.19 \pm 0.34 \mathrm{~Hz}$ to $0.05 \pm 0.05 \mathrm{~Hz}(n=6$; Fig. $9 F)$. Together, these results indicate that mENK inhibits both bursting and nonbursting $\mathrm{TH}$ neurons in the dmARC.
mENK activates GIRK channels coupling to both $\mu$ and $\delta$ opioid receptors

In the presence of TTX to block action potentials, $\mathrm{mENK}(3 \mu \mathrm{M})$ continued to attenuate membrane potential oscillations from $0.097 \pm 0.012 \mathrm{~Hz}$ to $0.002 \pm 0.001$ $\mathrm{Hz}(n=10$; Fig. $10 A, D)$, suggesting a direct inhibition. mENK can activate both $\mu$ and $\delta$ receptors with different affinities. To evaluate the contribution of both $\mu$ and $\delta$ receptors, we used the selective $\mu$ receptor antagonist CTAP and $\delta$ receptorselective antagonist SDM25N to test the effect of mENK on the bursting activity of $\mathrm{TH}$ neurons. In the presence of CTAP (1 $\mu \mathrm{M}), \operatorname{mENK}(3 \mu \mathrm{M})$ still almost completely abolished the bursting activity of TH neurons, decreasing the bursting frequency from $0.087 \pm 0.012 \mathrm{~Hz}$ to $0.008 \pm$ $0.007 \mathrm{~Hz}(n=10$; Fig. $10 B, D)$. In contrast, in the presence of SDM25N (1 $\mu \mathrm{M})$, $\operatorname{mENK}(3 \mu \mathrm{M})$ reduced this frequency to a lesser extent, inhibiting the bursting from $0.085 \pm 0.012 \mathrm{~Hz}$ to $0.055 \pm 0.015 \mathrm{~Hz}$ $(n=8$; Fig. $10 C, D)$. These results suggest that the $\delta$ opioid receptor is the primary receptor underlying mENK inhibition. The input resistance was reduced by mENK from $721 \pm 40 \mathrm{M} \Omega$ to $350 \pm 15$ $\mathrm{M} \Omega$, suggesting that $\mathrm{mENK}$ opens ion channels in $\mathrm{TH}$ neurons. To determine which ion channels contribute to $\mathrm{mENK}$ inhibition, we tested the effect of $\mathrm{Ba}^{2+}$ and GDP- $\beta$-S on mENK-evoked current. $\operatorname{mENK}(3 \mu \mathrm{M})$ activated a current of $9.6 \pm$ $1.0 \mathrm{pA}$ at a holding potential of $-60 \mathrm{mV}$ (Fig. 10G,H). Both $\mathrm{Ba}^{2+}(800 \mu \mathrm{M})$ and GDP- $\beta$-S (2 mM) completely abolished the mENK-evoked current (Fig. 10G,H). These results indicate that mENK activated GIRK channels.

In addition, we also measured the mENK-activated current at $-60 \mathrm{mV}$ in the presence of the subtype-selective opioid receptor antagonists CTAP and SDM25N. The current induced by $\operatorname{mENK}(3 \mu \mathrm{M})$ was $6.6 \pm 0.9 \mathrm{pA}(n=17$; Fig. $10 G, H)$ in the presence of CTAP ( 1 $\mu \mathrm{M})$, whereas in the presence of SDM25N ( $1 \mu \mathrm{M}), \operatorname{mENK}(3 \mu \mathrm{M})$ evoked a current of only $3.5 \pm 0.6 \mathrm{pA}(n=15$; Fig. $10 G, H)$. Therefore, $\sim 70 \%$ of the total mENK effect was mediated by $\delta$ receptors and $\sim 30 \%$ of the total current was mediated by $\mu$ receptors. We also applied a voltage ramp from -130 to $-30 \mathrm{mV}$ to determine the reversal potential of the mENK-induced current. The reversal potential was $-89.2 \pm 1.6$ $\mathrm{mV}$ based on data from 10 cells (Fig. $10 \mathrm{~J})$. The reversal potential was close to the $\mathrm{K}^{+}$equilibrium potential, indicating that $\mathrm{mENK}$ activated $\mathrm{K}^{+}$channels. The inhibition of mENK currents at all voltage levels by $\mathrm{Ba}^{2+}$ and 
A
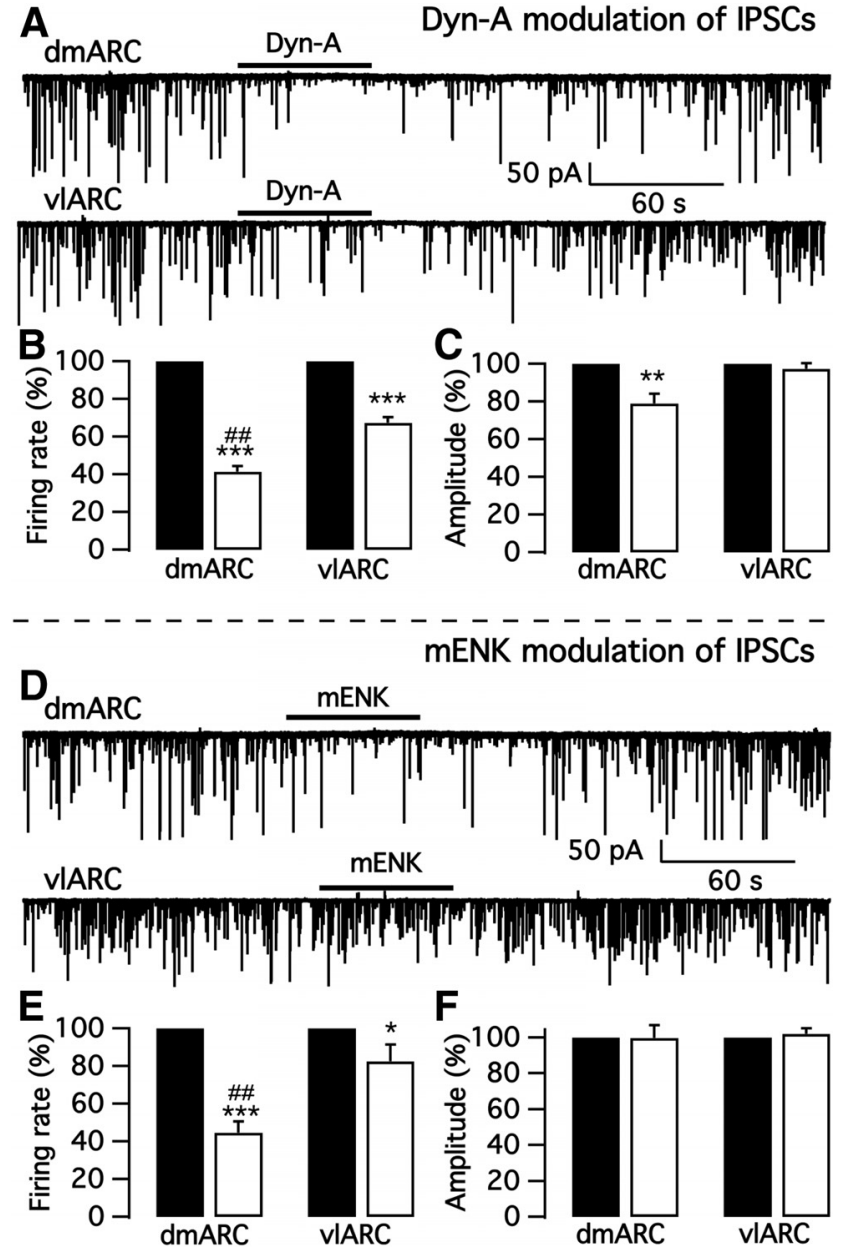

Figure 11. Dyn-A and mENK inhibit IPSCs in arcuate TH neurons. $A$, Representative traces showing Dyn-A actions on sIPSCs in a dmARC bursting TH neuron (top) and a vIARC nonbursting TH neuron (bottom). $\boldsymbol{B}$, Bar graph showing that sIPSCs in both dmARC and vIARC TH neurons were significantly inhibited by Dyn-A. Black bar, control; white bar, Dyn-A. C, Dyn-A attenuated the sIPSC amplitude of dmARC TH neurons but not that of vIARC neurons. D, Representative traces showing mENK inhibition of sIPSCs in a dmARC bursting TH neuron (top) and a vIARC nonbursting TH neuron (bottom). $\boldsymbol{E}$, Bar graph showing that sIPSC of both dmARC and vIARC TH neurons were significantly inhibited by mENK. Black bar, control; white bar, mENK. $\boldsymbol{F}$, No obvious effect of mENK on sIPSC amplitude was seen in either dmARC or vIARC TH neurons. ${ }^{*} p<$ $0.05,{ }^{* *} p<0.01,{ }^{* * *} p<0.001$ compared to control without neuropeptide application in the same ARC subregion, \#\#p<0.01 compared to neuropeptide application in vIARC.

GDP- $\beta$-S (Fig. 10J) provides further evidence that mENK activates GIRK channels in these cells.

Opioid peptides Dyn-A and mENK depress synaptic GABA release We also tested opioid peptides Dyn-A and mENK on spontaneous IPSCs (sIPSCs) in the presence of AP5 and CNQX to block ionotropic glutamate receptors. Dyn-A and mENK inhibited sIPSC frequency in both dmARC and vlARC TH neurons (Fig. 11). The inhibitory actions of both peptides on IPSCs were significantly greater in dmARC TH neurons than in vlARC neurons. Importantly, the inhibition of IPSCs is consistent with our findings above showing that ARC TH neurons release GABA. As both Dyn-A and mENK directly inhibited the ARC TH cells, the reduction in IPSC frequency could be due to inhibition of dopamine cells releasing GABA synaptically within the ARC, although the neuropeptides could also be acting by additional independent mechanisms.
A

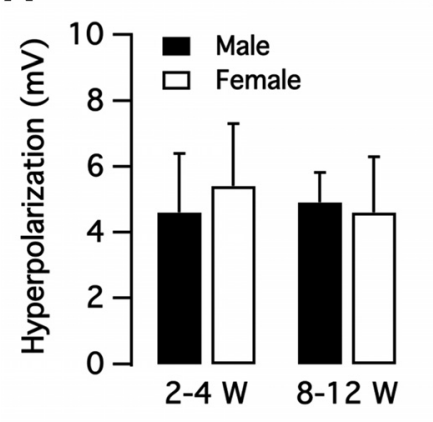

B

Dyn-A modulation

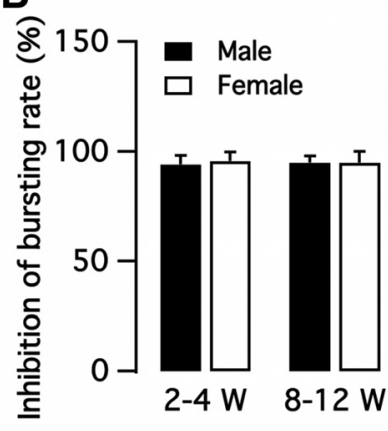

mENK modulation
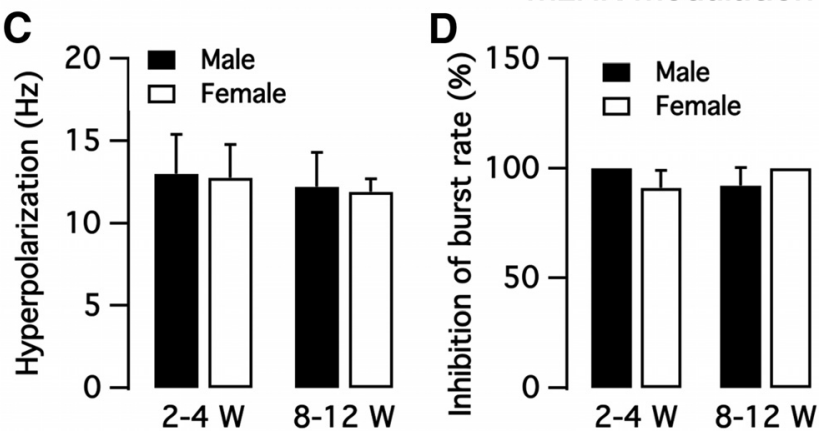

Figure 12. Comparison of opioid peptide responses in bursting neurons in male and female mice, and in mature versus immature mice. $\boldsymbol{A}$, Dyn-A hyperpolarizes membrane potential of bursting neurons from both male and female mice at age $2-4$ weeks and $8-12$ weeks. $B$, Dyn-A inhibition of bursting rate. $\boldsymbol{C}, \mathrm{mENK}$ hyperpolarizes bursting neuron membrane potential. $\boldsymbol{D}$, mENK inhibition of bursting rate.

Modulation by opioid peptides Dyn-A and mENK on bursting neurons from immature and mature male and female mice To explore whether gender and age affect Dyn-A and mENK actions, we compared the effect of the two neuropeptides on the activity of bursting neurons from immature and mature male and female mice. Little difference in Dyn-A or mENK responses was found in bursting neurons between male and female mice; similarly, little difference was found between immature and adult mice (Fig. 12).

Oxytocin excites both types of arcuate dopamine neurons

Similar to ARC dopamine neurons, oxytocin neurons also play a role in lactation. Here, we examined the effect of oxytocin $(1 \mu \mathrm{M})$ on bursting neurons. The mean membrane potential of bursting neurons was depolarized from $-68.7 \pm 1.8$ to $-59.3 \pm 1.9$ by oxytocin ( $n=15$ Fig. $13 C$ ). The firing rate was significantly increased from $1.6 \pm 0.4 \mathrm{~Hz}$ to $3.9 \pm 0.6 \mathrm{~Hz}(n=15$; Fig. $13 D)$. The total time of "burst ON" was increased from $24.1 \pm 3.9 \%$ to $67.0 \pm 8.0 \%$ of total time $(n=15$; Fig. $13 E)$, and the burst number per minute was increased from $2.6 \pm 0.6$ bursts to $5.2 \pm$ 0.5 bursts by oxytocin $(n=8$; Fig. $13 F)$. The firing pattern of 7 of 15 bursting neurons switched from bursting to tonic firing during oxytocin treatment and returned to bursting upon oxytocin washout, whereas the burst frequency of the other 8 cells was increased (Fig. 13A). Direct excitation of arcuate TH neurons by oxytocin was recently reported in rats (Briffaud et al., 2015).

We also tested the effect of oxytocin on nonbursting neurons. Oxytocin significantly depolarized the neurons from $-60.0 \pm 1.7$ $\mathrm{mV}$ to $-50.4 \pm 2.2 \mathrm{mV}$ and increased the firing rate from $0.27 \pm$ 


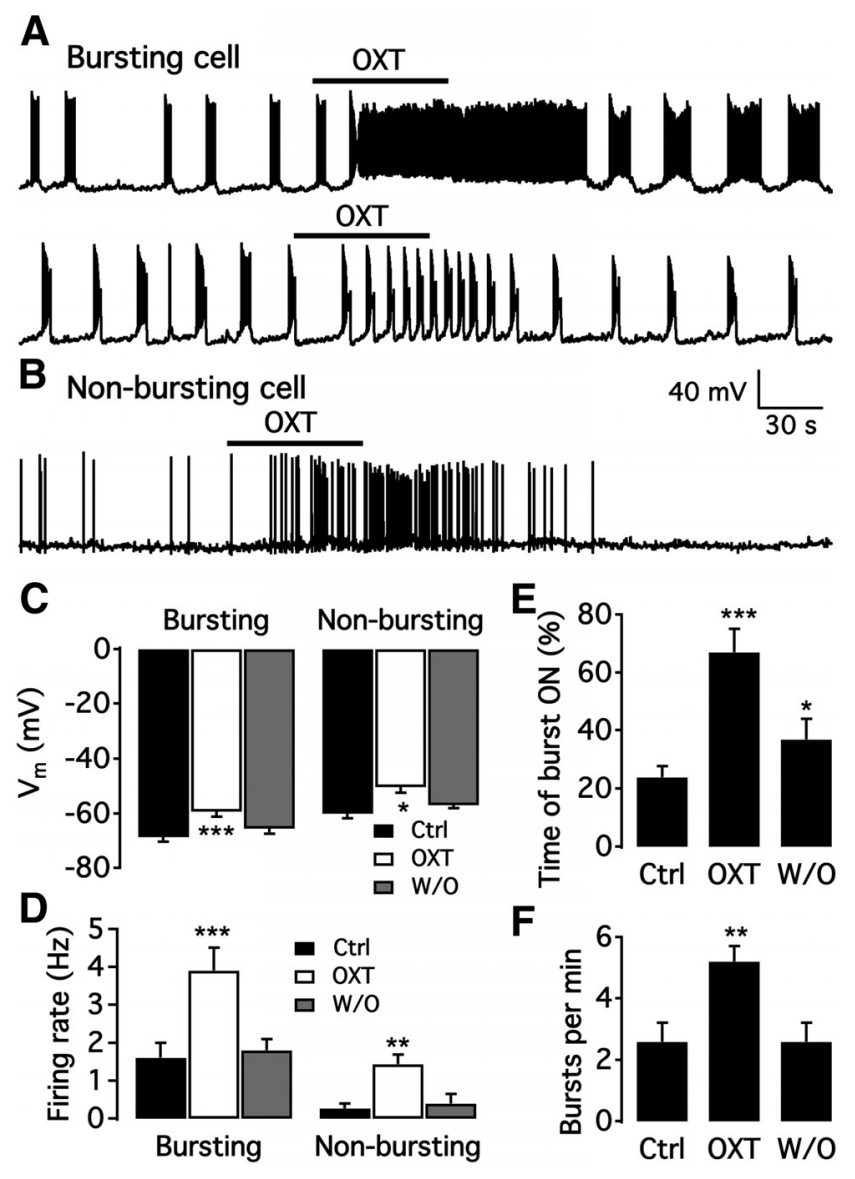

Figure 13. Oxytocin excites bursting and nonbursting neurons. $\boldsymbol{A}$, Representative trace showing oxytocin altered the firing pattern of a bursting neuron from burst firing to rapid tonic firing (top) and excited another dopamine neuron from a low burst rate to a higher burst rate (bottom). B, Example trace showing that oxytocin excited a nonbursting dmARC neuron. $\boldsymbol{C}$, Bar graph showing that oxytocin depolarized both bursting and nonbursting dmARC neurons. ${ }^{*} p<$ 0.05 (one-way ANOVA compared with control before OXT treatment). ${ }^{* * *} p<0.001$ (one-way ANOVA compared with control before OXT treatment). $D$, Summary of results showing oxytocin increased the firing rate of both bursting and nonbursting dmARC neurons. ${ }^{* *} p<0.01$ (oneway ANOVA compared with control before OXT treatment). ${ }^{* * *} p<0.001$ (one-way ANOVA compared with control before OXT treatment). $\boldsymbol{E}$, Summary of results showing oxytocin increased the time of "burst ON." * $p<0.05$ (one-way ANOVA compared with control before OXT treatment). ${ }^{* * *} p<0.001 . F$, Bar graph showing oxytocin increased burst number per minute of bursting neurons. ${ }^{* *} p<0.01$ (one-way ANOVA compared with control before OXT treatment).

$0.12 \mathrm{~Hz}$ to $1.43 \pm 0.26 \mathrm{~Hz}(n=7$; Fig. $13 B-D)$. Thus, oxytocin excited both bursting and nonbursting dmARC neurons.

\section{Discussion}

Here we find two subtypes of dorsomedial ARC dopamine neurons based on the electrophysiological properties and neuropeptide responses in 483 neurons. We used mice with a THpromoter to drive the transgenes. That most cells we studied in the $\mathrm{dmARC}$ are dopaminergic is supported by our immunostaining that revealed that the great majority (94\%) of TH cells here contained immunoreactive dopamine, leading us to the conclusion that although a small minority of dmARC TH cells may not contain dopamine, our results from a large number of cells are for the most part based on dmARC dopamine neurons. The membrane oscillations of bursting dopamine neurons depended on a mechanism involving T-type $\mathrm{Ca}^{2+}$ and A-type $\mathrm{K}^{+}$channel activation but were independent of gap junction coupling. The opi- oid neuropeptides Dyn and mENK inhibited both bursting and nonbursting dmARC cells, whereas oxytocin excited both types of neurons. We show for the first time that ARC TH neurons innervate each other and also innervate unidentified ARC neurons and release the fast inhibitory transmitter GABA presynaptically.

\section{Two subpopulations of ARC dopamine neuron}

In contrast to previous work that focused on bursting neurons as the primary dopamine neuron population in the rat dmARC (Lyons et al., 2010), in the present study based on a large number of recorded neurons, we identified two different subpopulations of neurons. Two-thirds of the cells showed bursting behavior, but another third were nonbursting. The A-type $\mathrm{K}^{+}$current was substantially different in the two cell types. Although perturbation of cell activity with optogenetics, current injection, or neurotransmitter stimulation might shift the cell to another transient state, the cell reverted to its prestimulation phenotype of bursting or nonbursting at the conclusion of the stimulation period, suggesting that the bursting phenotype was not simply a transient state of activation. In previous work (Lyons et al., 2010, 2012), most dopamine cells were identified electrophysiologically by bursting behavior, and therefore the study of nonbursting dopamine cells would have been reduced. In contrast, we use mice with reporter genes to identify cells for recording and found two types of dopamine neurons with different electrophysiological properties.

Previous studies showed that TH-positive cells in the rat dmARC (Everitt et al., 1984; van den Pol et al., 1984) were almost all immunoreactive for dopamine (Zoli et al., 1993). Although $\mathrm{TH}$-positive cells in both dmARC and vlARC project to the median eminence (Kawano and Daikoku, 1987), TH-positive cells in the vlARC may not show substantive dopamine or AADC immunoreactivity. That these vlARC cells constitute a different neuron population is consistent with three sets of our findings: (1) only $10 \%$ of the TH cells in vlARC contain detectable dopamine immunoreactivity compared with $94 \%$ in dmARC; (2) vlARC cells only rarely showed bursting behavior; and (3) unlike both bursting and nonbursting dmARC cells that were inhibited by Dyn, ventrolateral cells showed no detectable response to Dyn. The nonbursting TH neurons in the vlARC could be growthhormone releasing hormone neurons which coexpress $\mathrm{TH}$ (Meister et al., 1986; Zoli et al., 1993) and similar to ARC dopamine cells, also project to the median eminence to control pituitary secretions.

\section{Mechanisms of burst firing}

Burst firing enhances the efficacy of neuromodulator release and neurotransmission (Dutton and Dyball, 1979; Kim and McCormick, 1998; van den Pol, 2012). Bursting has been described in other populations of dopamine neurons. Substantia nigra dopamine neurons burst (Grace and Bunney, 1983, 1984) and dopamine release is enhanced by the burst (Gonon, 1988; Cooper, 2002). Rat ARC neurons showed rhythmic bursting oscillations by a mechanism based on neuron coupling by electrotonic (gap) junctions (Lyons et al., 2010). In the present study, we used transgenic mice that selectively expressed tdTomato in $\mathrm{TH}$ immunopositive neurons to identify neurons and found that two-thirds of the dmARC neurons display rhythmic oscillations with regular frequency. In contrast to the TTX block of membrane oscillations of dopamine neurons previously reported (Lyons et al., 2010), our data show that TTX only blocked action potentials but not the regular periodic membrane potential oscillations. In addition, in voltage-clamp with the membrane poten- 
tial held at -60 or $-70 \mathrm{mV}$, we did not detect the oscillations reported in rats (Lyons et al., 2010). Lyons et al. (2010) also reported that bursting was blocked by gap junction blockers; in contrast, we found little effect of the gap junction blockers carbenoxolone or $18 \beta$-GA on bursting even at high concentrations and long applications.

In mice, the oscillations were completely abolished by the broad-spectrum voltage-gated $\mathrm{Ca}^{2+}$ channel blocker $\mathrm{Cd}^{2+}$ and the T-type $\mathrm{Ca}^{2+}$ channel blocker $\mathrm{Ni}^{2+}$, indicating that the activation of T-type $\mathrm{Ca}^{2+}$ channels contributes to the regular bursting of ARC dopamine neurons. In addition, our data show that bursting neurons express A-type $\mathrm{K}^{+}$channels whose activation also contributes to bursting; A-type $\mathrm{K}^{+}$channel blockers changed the regular bursting to an irregular bursting pattern. In other neurons, low-threshold T-type $\mathrm{Ca}^{2+}$ channels play a role in burst firing (White et al., 1989). Our results indicate that both T-type $\mathrm{Ca}^{2+}$ channels and A-type $\mathrm{K}^{+}$channels contribute to burst firing in mice. Our data on the mechanisms underlying burst firing are substantially different from the previous report in several respects: we find that gap junctions are not required for bursting, that TTX does not block membrane potential oscillations, and that voltage clamp eliminated the membrane oscillations. The differences between our findings and those of Lyons et al. $(2010,2012)$ may be due to the different species used, mice in our studies and rats in the other, or to possible differences in experimental conditions; for instance, our recordings were done near body temperature, whereas the rat studies were done at room temperature.

\section{Robust local inhibitory axons within ARC}

Previous studies have focused almost exclusively on the projection of ARC dopamine cells to the median eminence. Here, we report substantive local projections from $\mathrm{TH}$ neurons to the majority of other TH neurons and to unidentified ARC neurons. That the majority of TH cells were synaptically inhibited by activation of ChIEF in TH-positive cells is consistent with dopamine neurons receiving synaptic contact from TH-positive cells in the ARC. A minority of cells expressing ChIEF showed little TH immunoreactivity; these cells could also contribute to synaptic release. Although it seems unlikely that these cells account for the substantial synaptic response detected, we cannot exclude the possibility that they may make some contribution to it. Our present study with optogenetic stimulation provides electrophysiological substantiation that ARC TH neurons release GABA. Optogenetic stimulation induced fast GABA synaptic currents with high fidelity, suggesting that GABA is released by ARC TH neurons and that these same cells respond to this synaptically released GABA. In addition, ARC TH neurons released GABA presynaptically onto unidentified neurons within the ARC. Our data are consistent with a previous suggestive observation that the number of IPSCs was greater during spike bursts than during silence in dopamine cells (Lyons et al., 2010). This unexplored projection of ARC TH neurons may modulate other systems within the ARC. Our data showing functional GABA release in the ARC support the possibility that ARC TH neurons also release GABA in the median eminence. GABA may directly affect the electrophysiological properties of pituitary cells and inhibit prolactin secretion (Taraskevich and Douglas, 1982; McCann and Rettori, 1986). Our data broaden our understanding that GABA coreleased from ARC TH neurons synaptically may provide an inhibitory feedback signal to other TH neurons to attenuate possible hyperexcitability, in addition to participating in other circuits within the ARC that may influence additional systems.

That ARC TH neurons release their neurotransmitters on other ARC neurons is consistent with the expression, albeit at low levels compared with substantia nigra dopamine neurons, of the inward dopamine transporter DAT (George and Van Loon, 1982; Storch et al., 2004). If the ARC cells only released dopamine into the portal circulation, there would be less need for a reuptake mechanism to remove extracellular transmitter.

\section{Neuropeptide modulation}

Both Dyn and mENK-immunoreactive axons appeared in close contact with dendrites and the soma of ARC TH neurons; because the majority of dmARC TH neurons showed apparent contact by these axons, we interpret this as contact with dopamine neurons. These connections with opioid peptide neurons support the possibility that endogenously released Dyn and mENK modulate the activity of ARC dopamine neurons. The inhibitory actions of Dyn-A and mENK were not affected by blocking synaptic transmission, suggesting a direct action of both neuropeptides. Our data with selective opioid receptor antagonists suggest that dopamine cells express $\kappa, \mu$, and $\delta$ receptors and therefore should be inhibited by most opioid neuropeptides. Based on previous findings that both Dyn and enkephalin increase prolactin secretion (Kiem et al., 1988; Butelman et al., 1999), the present study suggests that this may be based on a mechanism of direct inhibition of the dopamine cell. Lactating and nonlactating animals show similar proportions of different firing patterns in ARC dopamine neurons (Romanò et al., 2013), consistent with the view that opioids may act to enhance lactation not only by inhibiting electrical activity, but also by reducing dopamine synthesis (Arbogast and Voogt, 1996; Zhang et al., 2004).

Oxytocin excited most TH/DA neurons and switched the firing pattern from bursting to tonic firing. Because tonic firing may reduce the efficacy of neuromodulator release and neurotransmission (Dutton and Dyball, 1979; Kim and McCormick, 1998), dopamine release may be reduced by the switch from bursting to tonic firing and thus attenuate the inhibition of prolactin release. In a similar vein, thyrotropin-releasing hormone was proposed to increase prolactin release by switching burst firing of dopamine neurons to tonic firing to reduce dopamine release (Lyons et al., 2010).

\section{References}

Acuna-Goycolea C, Tamamaki N, Yanagawa Y, Obata K, van den Pol AN (2005) Mechanisms of neuropeptide Y, peptide YY, and pancreatic polypeptide inhibition of identified green fluorescent protein-expressing GABA neurons in the hypothalamic neuroendocrine arcuate nucleus. J Neurosci 25:7406-7419. CrossRef Medline

Andrews ZB, Grattan DR (2003) Opioid receptor subtypes involved in the regulation of prolactin secretion during pregnancy and lactation. J Neuroendocrinol 15:227-236. CrossRef Medline

Arbogast LA, Voogt JL (1996) The responsiveness of tuberoinfundibular dopaminergic neurons to prolactin feedback is diminished between early lactation and midlactation in the rat. Endocrinology 137:47-54. CrossRef Medline

Bayer VE, Pickel VM (1990) Ultrastructural localization of tyrosine hydroxylase in the rat ventral tegmental area: relationship between immunolabeling density and neuronal associations. J Neurosci 10:2996-3013. Medline

Ben-Jonathan N (1985) Dopamine: a prolactin-inhibiting hormone. Endocr Rev 6:564-589. CrossRef Medline

Ben-Jonathan N, Hnasko R (2001) Dopamine as a prolactin (PRL) inhibitor. Endocr Rev 22:724-763. CrossRef Medline

Björklund A, Dunnett SB (2007) Dopamine neuron systems in the brain: an update. Trends Neurosci 30:194-202. CrossRef Medline 
Briffaud V, Williams P, Courty J, Broberger C (2015) Excitation of tuberoinfundibular dopamine neurons by oxytocin: crosstalk in the control of lactation. J Neurosci 35:4229-4237. CrossRef Medline

Briski KP (1998) Glucoprivic induction of Fos immunoreactivity in hypothalamic dopaminergic neurons. Neuroreport 9:289-295. CrossRef Medline

Butelman ER, Harris TJ, Perez A, Kreek MJ (1999) Effects of systemically administered dynorphin A(1-17) in rhesus monkeys. J Pharmacol Exp Ther 290:678-686. Medline

Callahan P, Klosterman S, Prunty D, Tompkins J, Janik J (2000) Immunoneutralization of endogenous opioid peptides prevents the sucklinginduced prolactin increase and the inhibition of tuberoinfundibular dopaminergic neurons. Neuroendocrinology 71:268-276. CrossRef Medline

Cooper DC (2002) The significance of action potential bursting in the brain reward circuit. Neurochem Int 41:333-340. CrossRef Medline

Cusan L, Dupont A, Kledzik GS, Labrie F, Coy DH, Schally AV (1977) Potent prolactin and growth hormone releasing activity of more analogues of Met-enkephalin. Nature 268:544-547. CrossRef Medline

Dupont A, Cusan L, Labrie F, Coy DH, Li CH (1977) Stimulation of prolactin release in the rat by intraventricular injection of beta-endorphin and methionine-enkephalin. Biochem Biophys Res Commun 75:76-82. CrossRef Medline

Dutton A, Dyball RE (1979) Phasic firing enhances vasopressin release from the rat neurohypophysis. J Physiol 290:433-440. CrossRef Medline

Everitt BJ, Hökfelt T, Wu JY, Goldstein M (1984) Coexistence of tyrosine hydroxylase-like and gamma-aminobutyric acid-like immunoreactivities in neurons of the arcuate nucleus. Neuroendocrinology 39:189-191. CrossRef Medline

Foster GA, Hökfelt T, Coyle JT, Goldstein M (1985) Immunohistochemical evidence for phenylethanolamine- $\mathrm{N}$-methyltransferase-positive/tyrosine hydroxylase-negative neurones in the retina and the posterior hypothalamus of the rat. Brain Res 330:183-188. CrossRef Medline

Freeman ME, Kanyicska B, Lerant A, Nagy G (2000) Prolactin: structure, function, and regulation of secretion. Physiol Rev 80:1523-1631. Medline

George SR, Van Loon GR (1982) Characterization of high affinity dopamine uptake into the dopamine neurons of the hypothalamus. Brain Res 234:339-355. CrossRef Medline

Gonon FG (1988) Nonlinear relationship between impulse flow and dopamine released by rat midbrain dopaminergic neurons as studied by in vivo electrochemistry. Neuroscience 24:19-28. CrossRef Medline

Grace AA, Bunney BS (1983) Intracellular and extracellular electrophysiology of nigral dopaminergic neurons: 1 . Identification and characterization. Neuroscience 10:301-315. CrossRef Medline

Grace AA, Bunney BS (1984) The control of firing pattern in nigral dopamine neurons: burst firing. J Neurosci 4:2877-2890. Medline

Grattan DR, Pi XJ, Andrews ZB, Augustine RA, Kokay IC, Summerfield MR, Todd B, Bunn SJ (2001) Prolactin receptors in the brain during pregnancy and lactation: implications for behavior. Horm Behav 40:115-124. CrossRef Medline

Grimm D, Lee JS, Wang L, Desai T, Akache B, Storm TA, Kay MA (2008) In vitro and in vivo gene therapy vector evolution via multispecies interbreeding and retargeting of adeno-associated viruses. J Virol 82:58875911. CrossRef Medline

Hökfelt T, Johansson O, Fuxe K, Goldstein M, Park D (1976) Immunohistochemical studies on the localization and distribution of monoamine neuron systems in the rat brain: I. Tyrosine hydroxylase in the mes- and diencephalon. Med Biol 54:427-453. Medline

Ibata Y, Fukui K, Okamura H, Kawakami T, Tanaka M, Obata HL, Tsuto T, Terubayashi H, Yanaihara C, Yanaihara N (1983) Coexistence of dopamine and neurotensin in hypothalamic arcuate and periventricular neurons. Brain Res 269:177-179. CrossRef Medline

Javoy-Agid F, Ploska A, Agid Y (1981) Microtopography of tyrosine hydroxylase, glutamic acid decarboxylase, and choline acetyltransferase in the substantia nigra and ventral tegmental area of control and Parkinsonian brains. J Neurochem 37:1218-1227. CrossRef Medline

Jonsson G, Fuxe K, Hökfelt T (1972) On the catecholamine innervation of the hypothalamus, with special reference to the median eminence. Brain Res 40:271-281. CrossRef Medline

Kawano H, Daikoku S (1987) Functional topography of the rat hypothalamic dopamine neuron systems: retrograde tracing and immunohistochemical study. J Comp Neurol 265:242-253. CrossRef Medline
Kennett JE, McKee DT (2012) Oxytocin: an emerging regulator of prolactin secretion in the female rat. J Neuroendocrinol 24:403-412. CrossRef Medline

Kiem DT, Kanyicska B, Stark E, Fekete MI (1988) Prolactin release induced by opiate agonists, effect of glucocorticoid pretreatment in intact and adrenalectomized rats. Neuroendocrinology 48:174-179. CrossRef Medline

Kim U, McCormick DA (1998) The functional influence of burst and tonic firing mode on synaptic interactions in the thalamus. J Neurosci 18:9500 9516. Medline

Leshin LS, Kraeling RR, Kiser TE (1995) Immunocytochemical localization of the catecholamine-synthesizing enzymes, tyrosine hydroxylase and dopamine-beta-hydroxylase, in the hypothalamus of cattle. J Chem Neuroanat 9:175-194. CrossRef Medline

Leshin LS, Kraeling RR, Kineman RD, Barb CR, Rampacek GB (1996) Immunocytochemical distribution of catecholamine-synthesizing neurons in the hypothalamus and pituitary gland of pigs: tyrosine hydroxylase and dopamine-beta-hydroxylase. J Comp Neurol 364:151-168. CrossRef Medline

Lin JY, Pan JT (1999) Single-unit activity of dorsomedial arcuate neurons and diurnal changes of tuberoinfundibular dopaminergic neuron activity in female rats with neonatal monosodium glutamate treatment. Brain Res Bull 48:103-108. CrossRef Medline

Lin JY, Yen SH, Shieh KR, Liang SL, Pan JT (2000) Dopamine and 7-OHDPAT may act on $\mathrm{D}(3)$ receptors to inhibit tuberoinfundibular dopaminergic neurons. Brain Res Bull 52:567-572. CrossRef Medline

Lin JY, Lin MZ, Steinbach P, Tsien RY (2009) Characterization of engineered channelrhodopsin variants with improved properties and kinetics. Biophys J 96:1803-1814. CrossRef Medline

Lute B, Jou W, Lateef DM, Goldgof M, Xiao C, Piñol RA, Kravitz AV, Miller NR, Huang YG, Girardet C, Butler AA, Gavrilova O, Reitman ML (2014) Biphasic effect of melanocortin agonists on metabolic rate and body temperature. Cell Metab 20:333-345. CrossRef Medline

Lüthi A, Bal T, McCormick DA (1998) Periodicity of thalamic spindle waves is abolished by ZD7288, a blocker of Ih. J Neurophysiol 79:3284-3289. Medline

Lyons DJ, Horjales-Araujo E, Broberger C (2010) Synchronized network oscillations in rat tuberoinfundibular dopamine neurons: switch to tonic discharge by thyrotropin-releasing hormone. Neuron 65:217-229. CrossRef Medline

Lyons DJ, Hellysaz A, Broberger C (2012) Prolactin regulates tuberoinfundibular dopamine neuron discharge pattern: novel feedback control mechanisms in the lactotrophic axis. J Neurosci 32:8074-8083. CrossRef Medline

Matsushita N, Kato Y, Shimatsu A, Katakami H, Fujino M, Matsuo H, Imura $\mathrm{H}$ (1982) Stimulation of prolactin secretion in the rat by alpha-neoendorphin, beta-neo-endorphin and dynorphin. Biochem Biophys Res Commun 107:735-741. CrossRef Medline

McCann SM, Rettori V (1986) Gamma amino butyric acid (GABA) controls anterior pituitary hormone secretion. Adv Biochem Psychopharmacol 42:173-189. Medline

Meister B, Hökfelt T, Vale WW, Sawchenko PE, Swanson L, Goldstein M (1986) Coexistence of tyrosine hydroxylase and growth hormonereleasing factor in a subpopulation of tubero-infundibular neurons of the rat. Neuroendocrinology 42:237-247. CrossRef Medline

Melo SP, Lisowski L, Bashkirova E, Zhen HH, Chu K, Keene DR, Marinkovich MP, Kay MA, Oro AE (2014) Somatic correction of junctional epidermolysis bullosa by a highly recombinogenic AAV variant. Mol Ther 22: 725-733. CrossRef Medline

Meme W, Vandecasteele M, Giaume C, Venance L (2009) Electrical coupling between hippocampal astrocytes in rat brain slices. Neurosci Res 63:236-243. CrossRef Medline

Merchenthaler I (1994) Induction of enkephalin in tuberoinfundibular dopaminergic neurons of pregnant, pseudopregnant, lactating and aged female rats. Neuroendocrinology 60:185-193. CrossRef Medline

Moore KE, Demarest KT, Lookingland KJ (1987) Stress, prolactin and hypothalamic dopaminergic neurons. Neuropharmacology 26:801-808. CrossRef Medline

Pape HC (1996) Queer current and pacemaker: the hyperpolarizationactivated cation current in neurons. Annu Rev Physiol 58:299-327. CrossRef Medline

Pennock RL, Hentges ST (2014) Direct inhibition of hypothalamic pro- 
opiomelanocortin neurons by dynorphin A is mediated by the mu-opioid receptor. J Physiol 592:4247-4256. CrossRef Medline

Piotte M, Beaudet A, Joh TH, Brawer JR (1985) The fine structural organization of tyrosine hydroxylase immunoreactive neurons in rat arcuate nucleus. J Comp Neurol 239:44-53. CrossRef Medline

Plantjé JF, Steinbusch HW, Schipper J, Dijcks FA, Verheijden PF, Stoof JC (1987) D-2 dopamine-receptors regulate the release of $\left[{ }^{3} \mathrm{H}\right]$ dopamine in rat cortical regions showing dopamine immunoreactive fibers. Neuroscience 20:157-168. CrossRef Medline

Romanò N, Yip SH, Hodson DJ, Guillou A, Parnaudeau S, Kirk S, Tronche F, Bonnefont X, Le Tissier P, Bunn SJ, Grattan DR, Mollard P, Martin AO (2013) Plasticity of hypothalamic dopamine neurons during lactation results in dissociation of electrical activity and release. J Neurosci 33: 4424-4433. CrossRef Medline

Romero-Fernandez W, Borroto-Escuela DO, Vargas-Barroso V, Narváez M, Di Palma M, Agnati LF, Larriva Sahd J, Fuxe K (2014) Dopamine D1 and $\mathrm{D} 2$ receptor immunoreactivities in the arcuate-median eminence complex and their link to the tubero-infundibular dopamine neurons. Eur J Histochem 58:2400. CrossRef Medline

Ruggiero DA, Ross CA, Anwar M, Park DH, Joh TH, Reis DJ (1985) Distribution of neurons containing phenylethanolamine $\mathrm{N}$-methyltransferase in medulla and hypothalamus of rat. J Comp Neurol 239:127-154. CrossRef Medline

Savitt JM, Jang SS, Mu W, Dawson VL, Dawson TM (2005) Bcl-x is required for proper development of the mouse substantia nigra. J Neurosci 25: 6721-6728. CrossRef Medline

Sharifullina E, Ostroumov K, Grandolfo M, Nistri A (2008) N-methyl-Daspartate triggers neonatal rat hypoglossal motoneurons in vitro to express rhythmic bursting with unusual $\mathrm{Mg}^{2+}$ sensitivity. Neuroscience 154:804-820. CrossRef Medline

Steinbusch HWM, Tilders FJH (1987) Immunohistochemical techniques for light microscopical localization of dopamine, noradrenaline, adrenaline, serotonie and histamine in the central nervous system. In: IBRO handbook series: methods in the neurosciences (Steinbusch HWM, ed), pp 125-166. Chichester, United Kingdom: Wiley.

Steinbusch HW, de Vente J, Schipper J (1986) Immunocytochemisty of monoamines in the central nervous system. In: Neurology and neurobiology (Panula J, Pai-varinta H, Soinila S, eds), p 75106. New York: Alan R. Liss.

Storch A, Ludolph AC, Schwarz J (2004) Dopamine transporter: involvement in selective dopaminergic neurotoxicity and degeneration. J Neural Transm 111:1267-1286. CrossRef Medline

Sztainberg Y, Kuperman Y, Justice N, Chen A (2011) An anxiolytic role for CRF receptor type 1 in the globus pallidus. J Neurosci 31:17416-17424. CrossRef Medline
Taraskevich PS, Douglas WW (1982) GABA directly affects electrophysiological properties of pituitary pars intermedia cells. Nature 299:733-734. CrossRef Medline

Tritsch NX, Ding JB, Sabatini BL (2012) Dopaminergic neurons inhibit striatal output through non-canonical release of GABA. Nature 490:262-266. CrossRef Medline

Turiault M, Parnaudeau S, Milet A, Parlato R, Rouzeau JD, Lazar M, Tronche F (2007) Analysis of dopamine transporter gene expression pattern: generation of DAT-iCre transgenic mice. FEBS J 274:3568-3577. CrossRef Medline

van den Pol AN (2012) Neuropeptide transmission in brain circuits. Neuron 76:98-115. CrossRef Medline

van den Pol AN, Herbst RS, Powell JF (1984) Tyrosine hydroxylaseimmunoreactive neurons of the hypothalamus: a light and electron microscopic study. Neuroscience 13:1117-1156. CrossRef Medline

van den Pol AN, Yao Y, Fu LY, Foo K, Huang H, Coppari R, Lowell BB, Broberger C (2009) Neuromedin B and gastrin-releasing peptide excite arcuate nucleus neuropeptide $\mathrm{Y}$ neurons in a novel transgenic mouse expressing strong Renilla green fluorescent protein in NPY neurons. J Neurosci 29:4622-4639. CrossRef Medline

Van Vugt DA, Sylvester PW, Aylsworth CF, Meites J (1981) Comparison of acute effects of dynorphin and beta-endorphin on prolactin release in the rat. Endocrinology 108:2017-2018. CrossRef Medline

Vivar C, Traub RD, Gutiérrez R (2012) Mixed electrical-chemical transmission between hippocampal mossy fibers and pyramidal cells. Eur J Neurosci 35:76-82. CrossRef Medline

White G, Lovinger DM, Weight FF (1989) Transient low-threshold $\mathrm{Ca}^{2+}$ current triggers burst firing through an afterdepolarizing potential in an adult mammalian neuron. Proc Natl Acad Sci U S A 86:6802-6806. CrossRef Medline

Williams RG, Dockray GJ (1983) Distribution of enkephalin-related peptides in rat brain: immunohistochemical studies using antisera to metenkephalin and met-enkephalin Arg6Phe7. Neuroscience 9:563-586. CrossRef Medline

Zhang B, Hou Y, Voogt JL (2004) Effects of opioid antagonism on prolactin secretion and c-Fos/TH expression during lactation in rats. Endocrine 25:131-136. CrossRef Medline

Zhang X, van den Pol AN (2013) Direct inhibition of arcuate proopiomelanocortin neurons: a potential mechanism for the orexigenic actions of dynorphin. J Physiol 591:1731-1747. CrossRef Medline

Zoli M, Agnati LF, Tinner B, Steinbusch HW, Fuxe K (1993) Distribution of dopamine-immunoreactive neurons and their relationships to transmitter and hypothalamic hormone-immunoreactive neuronal systems in the rat mediobasal hypothalamus: a morphometric and microdensitometric analysis. J Chem Neuroanat 6:293-310. CrossRef Medline 